Below is the unedited draft of the article that has been accepted for publication

(C) Cognitive Processing, 2009, V. 10, No. 4, P. 293-326)

\title{
Is Our Brain Hardwired to Produce God, or is Our Brain Hardwired to Perceive God? A Systematic Review on the Role of the Brain in Mediating Religious Experience
}

\author{
Alexander A. Fingelkurts ${ }^{1 *}$, Andrew A. Fingelkurts ${ }^{1}$ \\ ${ }^{1}$ BM-Science - Brain and Mind Technologies Research Centre, Espoo, Finland
}

\begin{abstract}
To figure out whether the main empirical question "Is our brain hardwired to believe in and produce God, or is our brain hardwired to perceive and experience God?" is answered, this paper presents systematic critical review of the positions, arguments and controversies of each side of the neuroscientific-theological debate and puts forward an integral view where the human is seen as a psycho-somatic entity consisting of the multiple levels and dimensions of human existence (physical, biological, psychological, and spiritual reality), allowing consciousness $/ \mathrm{mind} / \mathrm{spirit}$ and brain/body/matter to be seen as different sides of the same phenomenon, neither reducible to each other. The emergence of a form of causation distinctive from physics where mental/conscious agency (a) is neither identical with nor reducible to brain processes and (b) does exert "downward" causal influence on brain plasticity and the various levels of brain functioning is discussed. This manuscript also discusses the role of cognitive processes in religious experience and outlines what can neuroscience offer for study of religious experience and what is the significance of this study for neuroscience, clinicians, theology and philosophy. A methodological shift from "explanation" to "description" of religious experience is suggested. This paper contributes to the ongoing discussion between theologians, cognitive psychologists and neuroscientists.
\end{abstract}

Keywords: Neuroscience; EEG; Brain; Cognitive processes; Consciousness; Mind; Soul; Spirit; Religious experience; God; Theology.

Canst thou by searching find out God? Job 11:7.

\section{Introduction}

The numerous studies in the fields of theology, cognitive psychology and neuroscience on the nature of religious experience (see reference list of this article) have lead some researchers to claim that religious experience is explained (Persinger 1984, 1991, 1993; Proudfoot 1985; Wuthnow 1992; d'Aquili and Newberg 1993, 1999; Boyer 2001, 2003; Atran 2002). Does this mean that the main empirical question "Is our brain hardwired to believe in and produce God, or is our brain hardwired to perceive God?" is answered? 
In order to figure out this we will provide systematic critical review of the positions, arguments and controversies of each side of the neuroscientific-theological debate and will offer our point of view on the matter. The review will include mostly practical/experimental/sociological studies, whereas broad theoretical/philosophical works will mostly be left out, as the works that greatly exceed its evidential grasp. The aim of this review is to critically examine the extent to which neuroscientific data of religious experience can be used to explain it. Additionally, biological framework of religious experience will be established and concrete research program will be offered. We will also outline main benefits of the research on religious experience and its importance to the fields of neuroscience, clinical studies, theology and philosophy. In this context we propose that this article be considered as a contribution to the ongoing discussion between theologians and neuroscientists.

\section{Definition of religious experience}

In order to undertake an adequate study of religious experience we need to define what religious experience is. Unfortunately, the terms used to define the religious experience differ across studies and researchers, and researchers have focused on different levels of its description.

Considering that religious experience is one of the three major components of religious activity, the other two components - belief and practice (James 1902; Previc 2006) - should be left out of the definition of the religious experience. However, religious belief and practice are often included explicitly or implicitly in the definition of the religious experience (Barrett and Keil 1996; Boyer 2003) ${ }^{1}$. This creates confusion in subsequent conceptualisations and dilutes the term religious experience in much wider phenomenon such as religious activity (see Runehov 2004).

Considering that religious experience is deeply subjective, we need to give a modern understanding what subjective experience is and how it differs from perception. According to the contemporary agreement in the professional community subjective experience is a phenomenal world inside the brain (so called "world-for-me") that is the collection of simultaneously present phenomena (such as seeing, hearing, touching, feeling, embodiment, moving, and thinking) that happen to a person right now (Revonsuo 2006). "Perception is a causal chain establishing systematic covariance between distal external states and the experiential states at the phenomenal level in the brain (as effect). [...] The

\footnotetext{
${ }^{1}$ See also a consensus conference of scientists interested in studying spirituality and religiousness which created the criteria for each definition (Larson et al. 1998).
} 
last link in the causal chain establishing accurate perception is the phenomenal level, bringing about or rather, being or constituting perceptual experience" (Revonsuo 2006; p. 129).

What is important here is the following: "Neither the phenomenal level as a whole nor any of its parts are somehow "perceived" themselves. That is, they do not serve as objects of perception in anything like the manner that external physical objects do. [...] The phenomenal level incarnates the ultimate realizer and presence of perceptual experience, not the objects of some further perceptual process or the modulator of some further state which could still be regarded as perceptual" (Revonsuo 2006; p. 129). This means that we do not perceive phenomenal objects at all; we simply experience patterns of activation at the phenomenal level of brain organization. In other words, phenomenal objects are self-presenting, - they do not exist without being experienced; they are constitutive of the experience (Revonsuo 2006).

Now, let us look closely at religious experience per se. Phenomenologically religious experience consists of both explicit components (e.g., "visions," "voices", etc.) and vague (numinous) components that often have an emotional flavour (Previc 2006). According to Hardy (1979, as cited by Saver and Rabin 1997), Beauregard and Paquette (2006), and Cahn and Polich (2006) the most prevalent numinous experiences include: (1) a sense of special patterning of events in a person's life by a divine being; (2) an awareness of the presence of a divine being; (3) a sense of union with a divine being or the divine universe; (4) an awareness of receiving help in answer to a prayer; (5) an awareness of being looked after or guided by a presence of God; (6) an awareness of a divine presence in nature; (7) experiencing in an extraordinary way that all things are "One" with a divine being; (8) the sense of having touched the ultimate ground of divine reality; (9) the experience of timelessness and spacelessness; (10) feelings of positive affect, peace, joy and unconditional love; (11) a metacognitive ${ }^{2}$ shift in the relationship between thoughts and feelings - they come to be observed as arising phenomena instead of occupying full attention; and (12) blissful absorption into the present moment.

Together these explicit and numinous components can be present in a religious experience in any combination. Together they address all known cultural expressions of religion experience. Here we would like to stress that religious experience is not the result of person's observations and reflection, rather it comes to the mind's eye at once in complete internal integrity. Often religious experience arises (a) spontaneously in the most prosaic of circumstances, outside any tradition of religious doctrine and

\footnotetext{
2 Metacognition refers to thinking about cognition (memory, perception, calculation, association, etc.) itself or to thinking/reasoning about one's own thinking (Metcalfe and Shimamura 1994).
} 
practice and (b) involuntary, where individual does not feel that he/she is the agent or cause of his/her own experience (Taves 2005).

Moreover, religious experience has two common yet very important characteristics: (a) it is invariably experienced as being real, even more real than the baseline reality ${ }^{3}$ of every day life (for an extensive discussion on the reality issue, see Newberg and Lee 2005) and (b) it is characterised by the intense memorability.

Thus, based on the reasoning set out above, we can construct the following definition of religious experience: religious experience is the very moment of experiencing of ultimate divine reality or ultimate divine truth, a transcendence of events or universe, timelessness, spacelessness, and divine being and/or union with it in any combination with an accompanied memorable feeling of reality, emotions and thoughts with a religious content.

We use the word "religious" instead of "mystic" or "spiritual", because "religious" in our opinion is a narrower concept and also adds a cultural dimension. The cultural dimension is important because any experience is always subjective and personal, and each individual is inserted in a particular cultural environment. In the mystical experience, all 'otherness' disappears and the person becomes one with the transcendent. The person discovers that he or she is not distinct from the cosmos or the other reality but one with it. Here God or divine evaporates into abstract Ideality. Spiritual experience concerns experience of or communion with supernatural beings (the spirit(s)) or phenomena. Here, besides God a wide range of supernatural beings can be experienced: spirits of dead relatives, spirits of plants and animals and so on. Religious experience, however, relates to or consists of transcendent God or divine realm.

Taken together above mentioned reasoning, we have a narrow definition of religious experience which leaves out such components of religious activity as belief and practice, does not include such supernatural beings and/or phenomena as spirits of dead relatives, plants or animals and does not include extrovertive experiences (Marshall 2005) where features such as unity, knowledge, reality, love, luminosity and so forth, characterize experience of the natural world, but not the experience of something beyond the natural world such as a transcendent God or divine realm. At the same time, this definition is broad enough to pick out all known characteristics of religious experience and it permits culturally flavoured expression of God or divine.

\footnotetext{
${ }^{3}$ Baseline reality is the reality that comprises our everyday perceptions and behaviours.
} 
Since we have a definition of religious experience which clearly distinguishes it from other phenomena, we now need a proper conceptualisation of religious experience on the basis of what is known about it from practical/experimental and sociological studies.

\section{History of religious experience}

There is indirect evidence that the history of religious experience spans over 40,000 years. Indeed, it has been well established that Neanderthals (Trinkaus and Shipman 1993) and other homo sapiens of the Middle Paleolithic (e.g. 150,000 to 35,000 B.P. ${ }^{4}$ ) and Upper Paleolithic (35,000 B.P. to 10,000 B.P.) engaged in complex religious rituals (Joseph 2001). Moreover, primitive religious concepts (such as the concept of death) were already present in Neanderthals while the first clear evidence of mythical creatures in cave drawings (e.g., half-man, half-god) appeared approximately 40,000 years ago (Mithen 1996, 1999).

Religious rituals and drawings by themselves are not evidence of religious experience but one can suppose that it is a religious experience that drives the development of religious rituals and the establishment of religious drawings. Such an assumption is supported by the fact that all higher vertebrate forms (including humans) demonstrate experience-dependent behaviour (along with other types of behaviour), i.e. an adaptive change of behaviour as a result of experience. Additionally, LewisWilliams and Dowson (1988) have shown that cave bizarre drawings bear a close association with the entopic visual experiences.

Several aspects are important for our conceptualization in this brief review:

(1) Religious experience has a very long history (over 40,000 years). Thus, it is not a transient or temporary phenomenon in human history.

(2) Available (even though limited) data suggests that religious experience appeared much later than the modern human being came onto the scene. Thus, the gap that exists between the development of anatomically modern humans $(\approx 200,000$ years ago, McDougall et al. 2005) and the appearance of religious experience (over 40,000 years ago) raises the possibility that other factors besides the brain anatomy or morphology (size and shape) may have played a role in the emergence of mind or mental properties.

\footnotetext{
${ }^{4}$ Raw, i.e. uncalibrated, radiocarbon ages are usually reported in radiocarbon years "Before Present" $(B P)$.
} 
(3) At the same time, available (but limited) data suggests that religious experience appeared almost simultaneously with such pre-cultural phenomena as language, drawings and rituals (Logan 2006). However, it is only much earlier the time when culture starts to exert its own strong influence on the way the individual perceives his/her environment and shapes his/her experience. Thus, we cannot conceptualise religious experience as a by-product of culture.

\section{Universality of religious experience}

It seems that religious experience was and is a world-wide phenomenon. According to Burkert (1996) in prehistoric times no groups of people lived which had no religious experience (judging by the existence of religion). At the same time, groups existed which have no demonstrated such attributes of human culture as agriculture, clothing, money, laws and writing.

It is not uncommon for people to have a religious experience. All surveys since the 1960s indicated that $30-40 \%$ of respondents have had at least one or two religious experiences (Spilka et al. 1984); Gallop polls in the 1990s found that 53\% of American adults had had religious experience (Gallup and Castelli 1990). In general, about 20-53\% of all religious persons actually claim to have had such an experience (Saver and Rabin 1997). The National Survey of Youth and Religion found that $80 \%$ of teens reported having at least one type of religious experience (Smith and Denton, 2005). These values are especially interesting if one considers the number of atheists ${ }^{5}+$ agnostics $^{6}$. According to Harris Interactive poll (2006) the number of atheists + agnostics is $18 \%$ (United States), $52 \%$ (Great Britain), 64\% (France), 45\% (Germany), 41\% (Spain) and 27\% (Italy). According to Eurostat survey (Eurobarometer poll 2005) the number of non-believers ${ }^{7}$ is $23 \%$ (Sweden), 22\% (Luxemburg), 27\% (Belgium), 27\% (Netherland), 30\% (Czech Republic), 26\% (Estonia) and 18\% in average for 25 countries of Europe.

It is striking that people from different religions (and cultures) experience certain common religious phenomena, for example the feeling of timelessness, divine love and being at one with the divine universe or divine being (Runions 1979; Hay 1990; Runehov 2004). Such commonality of experience Jung and von Franz (1964) described as "archetypal" - inborn tendencies to produce, create and respond in a similar and particular manner to specific images and stimuli.

\footnotetext{
${ }^{5}$ Atheist - one who denies the existence of God.

${ }^{6}$ Agnostic - one who is sceptical about the existence of God but not an atheist.

${ }^{7}$ Non-believer - one who does not believe neither in any sort of spirit, God, or life force.
} 
It is also important to note that besides the fact that common religious experiences exist in all religions and cultures, religious experience exists also in all stages of individual development: from infancy through adolescence and into adulthood (Fowler 1981; Oser 1991; Tamminen 1994). Indeed, the literature in this field attests to the existence of profound religious experiences in children (see Robinson 1983; Armstrong 1985; Coles 1990; Stower and Ryan 1998). This experience in children may be conditioned by children's "intuitive theism" (default theory of the world) which is independent on cultural-environmental input such as parents' religiosity (atheism/theism), storybooks and family conversations (Evans 2000, 2001; Barrett and Richert 2003; Bering 2004; Kelemen 2004; Kelemen et al. 2005; Richert and Barrett 2006; Bloom 2007).

Summarising, we can note that:

(1) The common phenomenon of 'religious experience' exists in all religions and cultures. This suggests that there should be a reason for such commonality; otherwise this religious experience cannot survive through evolution. Indeed, why would the brain have evolved the systems that enable the humans to experience something that does not exist?

(2) Religious experience exists in all stages of individual development starting from infancy and may happen in children whose parents are atheists. The pressure of culture is not strong in infancy (if nonexistent at all); therefore religious experience should not be conceptualised as a consequence of cultural influence.

(3) The above facts highlight that religious experience is a fundamental and universal characteristic of human being.

\section{Variations of one religious experience versus a continuum of many religious experiences}

It is well known that religious experience can appear either naturally (in healthy people and without chemical interventions), either during psychiatric diseases (temporal lobe epilepsy, mania, obsessivecompulsive disorder and schizophrenia; for the references, see Table 1), or under the influence of psychotropic agents (phencyclidine, ketamine, amphetamines, LSD, psilocybin, mescaline and salvatorin A; for the references, see Table 2) and brain stimulation (Makarec and Persinger 1985). 
Table 1. Summary of studies on religious experience during psychopathologies.

\begin{tabular}{|c|c|c|c|c|}
\hline References & $\begin{array}{l}\text { Temporal lobe } \\
\text { epilepsy }\end{array}$ & $\begin{array}{l}\text { Schizophrenia/ } \\
\text { schizotypy }\end{array}$ & $\begin{array}{l}\text { Bipolar disorder } \\
\text { (mania/hypomania) }\end{array}$ & $\begin{array}{l}\text { Obsessive-compulsive- } \\
\text { disorder }\end{array}$ \\
\hline review by Joseph, 2001 & + & & & \\
\hline Waxman \& Geschwind, 1975 & + & & & \\
\hline Bear \& Fedio, 1977 & + & & & \\
\hline Bear, 1979 & + & & & \\
\hline Bear et al., 1982 & + & & & \\
\hline review by Csernansky et al., 1990 & + & & & \\
\hline review by Saver \& Rabin, 1997 & + & & & \\
\hline Wuerfel et al., 2004 & + & & & \\
\hline MacDonald \& Holland, 2002 & + & & & \\
\hline Morneau et al., 1996 & + & & & \\
\hline Persinger, 1984 & + & & & \\
\hline Diduca \& Joseph, 1997 & & + & & \\
\hline White et al., 1995 & & + & & \\
\hline Feldman \& Rust, 1989 & & + & & \\
\hline Peters et al., 1999 & & + & & \\
\hline Spencer, 1975 & & + & & \\
\hline Fenwick et al., 1985 & & + & & \\
\hline Cothran \& Harvey, 1986 & & + & & \\
\hline Getz et al., 2001 & & + & & \\
\hline Buckley, 1981 & & + & & \\
\hline review by Previc, 2006 & + & + & + & + \\
\hline Brewerton, 1994 & & + & + & \\
\hline Kroll \& Sheehan, 1989 & & + & + & \\
\hline Gallemore et al., 1969 & & & + & \\
\hline review by Lewis, 1994 & & & & + \\
\hline Tek \& Ulug, 2001 & & & & + \\
\hline Tolin et al., 2001 & & & & + \\
\hline Fiske \& Haslam, 1997 & & & & + \\
\hline
\end{tabular}


Table 2. Psychotropic drugs and religious experience.

\begin{tabular}{|c|c|c|c|c|c|c|c|c|}
\hline & glutamate system & \begin{tabular}{|l|} 
dopamine \\
system
\end{tabular} & \multicolumn{5}{|c|}{ serotonine system } & $\begin{array}{l}\text { opioid } \\
\text { system }\end{array}$ \\
\hline References & 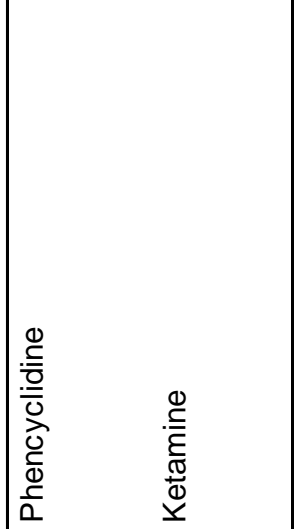 & 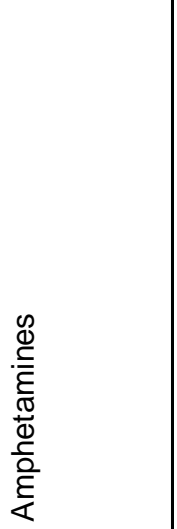 & 仓ิ & $\begin{array}{l}\frac{\bar{c}}{0} \\
\frac{0}{0} \\
\frac{0}{\bar{n}} \\
\frac{0}{0}\end{array}$ & 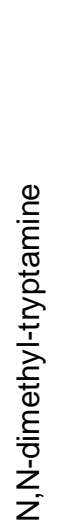 & 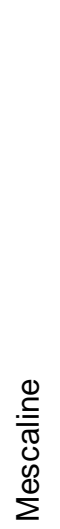 &  & . \\
\hline $\begin{array}{l}\text { Hansen et al., } 1988 \\
\text { Rosse et al., } 1994 \\
\text { Mandell, } 1980 \\
\text { Wright, } 1989 \\
\text { Unger, } 1963 \\
\text { Aghajanian \& Marek, } 1999 \\
\text { Glennon, } 1990 \\
\text { Freese et al., } 2002 \\
\text { Roth et al., } 2002\end{array}$ & $\begin{array}{ll}+ & + \\
+ & +\end{array}$ & $\begin{array}{l}+ \\
+\end{array}$ & $\begin{array}{l}+ \\
+ \\
+ \\
+\end{array}$ & $\begin{array}{l}+ \\
+ \\
+ \\
+\end{array}$ & $\begin{array}{l}+ \\
+ \\
+\end{array}$ & $\begin{array}{l}+ \\
+ \\
+ \\
+\end{array}$ & $\begin{array}{l}+ \\
+ \\
+\end{array}$ & + \\
\hline
\end{tabular}

This raises another important issue: are there many variations of a single religious experience or is there a continuum of many different religious experiences. Several converging lines of evidence suggested that there is a state of religious experience (a naturally occurring state in healthy people and without chemical interventions) and there are several altered states with a religious content (appearing during psychiatric diseases or under the influence of drugs). Let us look at these pieces of evidence more closely:

(a) Although many people with psychopathological disorders may have religious experience, religious experience does not always occur in a pathological state in a previously healthy person.

(b) Not all people with psychopathological disorders have religious experience.

(c) Religious experience in the general population is negatively associated with psychoticism ${ }^{8}$, depression and other mental illnesses (Batson and Ventis 1982; Francis and Wilcox 1996; Maltby

\footnotetext{
${ }^{8}$ Psychoticism is one of the three traits of personality. High levels of this trait are believed to be linked to increased vulnerability to psychoses such as schizophrenia (Eysenck and Eysenck 1976).
} 
1997; Roman and Lester 1999) so that religious experience in the vast majority of individuals is associated with non-pathological brain activity.

(d) Patients with religious obsessions do not fundamentally differ from those with non-religious obsessions in terms of their religious practice and obsessive-compulsive-disorder symptoms (e.g., severity, frequency and type) (Tek and Ulug 2001).

(e) Cultural and other factors determine to a great extent whether schizophrenic delusions take on a religious flavour or not. For example, grandiosity delusions may be supplanted with religious ones as the patient ages (Verdoux et al. 1998), religious delusions may give way to non-religious ones as a particular society becomes less religious (Klaf and Hamilton 1961): preoccupations and delusions of a religious nature in British schizophrenics decreased strongly between the mid-19th century and the mid-20th century, while those of a sexual character increased. Additionally, religious delusions seem to be much more common in more religious or magical societies (e.g., religious delusions are low in China but are higher in Korea and Jamaica and are significantly more prevalent among Protestants than Catholics) (Getz et al. 2001; Kim et al. 2001; Ndetei and Vadher 1985).

(f) Not all subjects who consumed psychedelic drugs ${ }^{9}$ reported religious experience; only about a third of all subjects had such an experience (Leary 1964; Leary and Clark 1963; Clark 1969).

(g) It has been shown that meditation produces no effect on brain electrical activity when subjects have been given either an opiate or benzodiazepine antagonist ${ }^{10}$ (Sim and Tsoi 1992).

(h) Periods of religious experience for healthy people are rather brief, while persons with psychopathology have some kind of 'constant' intruder. Moreover, whereas the healthy person can conceptualise about the universe or God and remain intact, the patient with psychopathology is lost into confusion and is ultimately deprived of his concept of boundaries (Runehov 2004).

(i) 'Normal' people have reported that their religious experience is more real than baseline reality, even when they are recalled from within baseline reality (Bucke 1961; Newberg and d'Aquili 1994; Newberg et al. 2001; for an extensive discussion on the reality issue, see Newberg and Lee 2005). At the same time, 'normal' individuals almost always refer to dreams as inferior to baseline reality

\footnotetext{
${ }^{9}$ Psychedelics are psychoactive drugs whose primary action is to alter the thought processes of the brain. They induce intense and distorted sensory perceptions, hallucinations, feelings of euphoria or sometimes despair, and altered states of awareness or sometimes states resembling psychosis.

${ }^{10}$ In medicine, the term opiate describes any of the narcotic substances (alkaloids) found in opium. The benzodiazepines are a class of psychoactive drugs considered as minor tranquilizers with varying hypnotic, sedative, anxiolytic, anticonvulsant, muscle relaxant and amnesic properties, which are brought about slowing down the central nervous system. In pharmacology an antagonist is a binding partner of a receptor that inhibits the function of an agonist (a substance that binds to a specific receptor and triggers a response in the cell).
} 
when they are recalled and discussed within baseline reality. The same inferior feeling is true for psychotic hallucinations - after they are cured by psychotropic medications. A person having emerged from such a psychotic state will recall it as psychotic (Newberg and Lee 2005).

(j) Healthy adolescents reported a greater frequency of religious experiences than did their inpatient peers (Grossoehme et al. 2007).

Thus, there appears to be a clear distinction between spiritual pathology, pharmacologically induced spirituality and non-pathological religious experience.

\section{Heredity and religious experience}

Studies of identical versus fraternal twins have suggested a genetic contribution to the tendency of a human to have a religious experience (Waller et al. 1990; D’Onofrio et al. 1999a,b; Eaves et al. 1990; Eaves 2004). For example, in study by Truett et al. (1992) who used 3.810 pairs of twins found that about $16 \%$ of the variance in their religiosity was due to heredity. Using mostly very large samples of twins (3.000-14.000 pairs of twins), behaviour geneticists have shown that genetic factors manifest a moderate degree of influence on religious devotion and conservatism (D’Onofrio et al. 1999a,b).

A twins and adoption study has reported that genetic variation contributes to about $50 \%$ of individual variation in religiosity (Bouchard et al. 1990). This research is in line with Waller et al. (1990) who studied the relationship between heredity and environment on the religiosity in 53 pairs of monozygotic twins (identical) and 31 pairs of dizygotic twins (fraternal) who had been reared apart and 458 pairs of identical and 363 pairs of fraternal twins who were raised together and found that about $50 \%$ of the variation in the religiosity was a function of genetic influences. Their analyses suggested that familial-environmental factors played at most a minor role in their religiosity dimensions.

More recently, Kirk et al. (1999) confirmed that genetic makeup is responsible for approximately $50 \%$ of the variation in religiousness - including spiritual feelings and beliefs - from within twin siblings. They also reported that the heritability of self-transcendence was estimated to be approximately $41 \%$ in women and $37 \%$ in men. Recent research on twins has generally confirmed this conclusion (Olson et al. 2001). Additionally, it was shown that religiosity appears to be influenced by heredity to about the same degree as intelligence (Previc 2006).

Thus, on the basis of these studies, there is reason to believe that religious experience has a biological basis. In another words, an appropriate biological basis is needed for a religious experience to occur. 
Based on this short review, we can conclude that religious experience is not determined by environmental and cultural factors, rather it is modulated by them. Here we stress that social and cultural contexts are heavily influenced and even limited by the human's biological nature. Any cultural characteristic takes as a given, a starting point, the innate biological characteristics of the human. However, many of these characteristics exist as potential and can be realised only in interaction with the environment.

The existence of a biological basis for religious experience suggests the significance of biological knowledge for theology (for discussion, see Clayton 2000). Here we need to understand whether biological peculiarities reflect the divine influences or ultimately physical influences. Clayton (2000) offered the following logic: "If biological explanations are ultimately nomological (law-based) in the strong way that physical explanations are, then there will be no room for divine influence; if they exhibit causal influences analogous to the way that one thought can (non-nomologically) influence another, then there will be room in principle" for divine influence.

\section{Evolution and religious experience}

Speaking about biology and religious experience, Joseph (2001) asks the following question: if there is no divine entity in the world then why has our brain become adapted for perceiving and experiencing what supposedly does not exist? Here the issue of evolution is raised ${ }^{11}$. Joseph suggested that we are able to hear and see because there were and are vital auditory and visual stimuli in the surrounding environment; and in order to perceive and analyse this information, the human brain possessed specialised structures or circuits capable of doing so. According to Joseph (2001) the same evolutionary principles should be applied to religious experience.

Therefore, from an evolutionary point of view, religious experience must contribute to the survival of those capable of experiencing it. In another words it should be adaptive. The adaptationist view is supported by the fact that the religious communities were far more likely to outlast their nonreligious counterparts - four times as likely in any given year (Sosis 2000; Sosis and Bressler 2003). Joseph speculates that those who evolved a religious-moral conscience capable of redirecting and controlling the dangerous limbic ${ }^{12}$ impulses, were more likely to survive, and, presumably, more likely

\footnotetext{
${ }^{11}$ The quest for an evolutionary basis of religious experience is not new (see Walter 1995).

${ }^{12}$ The limbic system includes the structures in the human brain involved in emotion, motivation, and emotional association with memory.
} 
to successfully breed (Joseph 2001). This idea is in line with the fact that religious experience has some protection against certain types of mental and physical ill-health (see reviews in Koenig and Cohen 2002; Marks 2005) and this "power" of religious experience has very likely contributed to its evolutionary success.

Another point of view is that religious cognition is a by-product of the evolved mind and as such, religious experience has no adaptive value per se. Selection may preserve religious tendencies because it preserves the more broadly functional design that produces them (for general overviews see Barrett 2000; Boyer 2001, 2003). For example, Previc (2006) suggested that religious experience co-evolved with an expansion of the dopaminergic (DA) brain system and with such DA-mediated phenomena as abstract reasoning. See Table 3 for a list of the known functions of DA and other neurotransmitter brain systems involved in religious experience.

Table 3. Known functions of the neuronmediator's systems which have been reported to be involved/modulated/(de)activated during religious experience.

\begin{tabular}{|c|c|c|}
\hline Neuronmediator's systems & Functions & References \\
\hline Dopaminergic & $\begin{array}{l}\text { Speeds up the internal clock; promotes internal noise and loosened associations; mediates abstract reasoning; } \\
\text { reduces perceptual sensitivity; involved in brain reward function and appetitive motivation processes; dopamine neurons } \\
\text { participate in the modulation of expectation, memory, activity, attention, drives, and mood; plays role in emotional tone }\end{array}$ & $\begin{array}{l}\text { Meck, 1996; Shaner, 1999; review by Previc, 2006; } \\
\text { Krummenacher et al., 2002; Bozarth, 1991; } \\
\text { Cohen \& Carlezon, } 2007\end{array}$ \\
\hline Acetylcholinergic & $\begin{array}{l}\text { Elevated during dreaming and decreased during most hallucinations; is involved in behavioural inhibition; controls the } \\
\text { learning rate, which determines when to learn something new and when to retain what has been memorized; }\end{array}$ & review by Previc, 2006; Carlton, 1963; Doya, 2000 \\
\hline Serotoninergic & $\begin{array}{l}\text { Decreased during dreaming and hallucinations; includes inhibition of sensory stimuli and arousal; play an important } \\
\text { part of the biochemistry of depression, bipolar disorder and anxiety }\end{array}$ & review by Previc, 2006; Borg et al., 2003 \\
\hline Glutamatergic & $\begin{array}{l}\text { The interaction with the dopamine plays an essential role in mediating loss of consciousness; is implicated in epileptic } \\
\text { seizures and in the acquisition of conditioned fear and anxiety; participates in the pathophysiology of schizophrenia } \\
\text { and major depression; plays an "endocrine-like" role as part of a larger homeostatic system; is involved in most } \\
\text { aspects of normal brain function including cognition, memory and learning }\end{array}$ & $\begin{array}{l}\text { Smythies, J. 1999a,b; review by Tsapakis \& Travis, } \\
\text { 2002; review by Moghaddam, 2003; Fernstrom \& } \\
\text { Garattini, 1998; Danbolt, } 2001\end{array}$ \\
\hline
\end{tabular}

Even though different authors have emphasised different aspects of the evolutionary process in relation to the religious experience, one can derive a common denominator: as organisms become organised in more and more complicated ways, new properties emerge. Although the manifestation of new properties is dependent on the laws of physics, their behaviour is irreducible to any of the underlying levels (emergence principle ${ }^{13}$ ). At each level of emergence, new structures are created and new causal forces are at work (Clayton 2006). In this sense, according to Clayton (2007), divine entity "could guide the process of emergence through the introduction of new information (formal causality)

\footnotetext{
${ }^{13}$ Emergence refers to the way a complex system and pattern arises out of a multiplicity of relatively simple interactions and the complexity of this system makes possible types of phenomena which could not be generated by the components alone or summed together (Kim 1992).
} 
and by holding out an ideal or image that could influence development without altering the mechanical mechanisms of evolution or adding energy from outside (final causality)."

Indeed, during the course of evolution there emerged a level at which entities within the universe became capable of acting according to explicit conscious purposes. At that point conscious persons emerged capable of being affected by and affecting other conscious beings, in a manner fully consistent with, though also going beyond, the laws of physics (Clayton 2000). Here, one can speak about a totally new level of experience, behaviour and causal forces which are different from physical ones: human thoughts, human intentions, human decision-making and human symbolic interactions including language, culture and art and senses of truth and justice. Thus, in humans nature becomes aware of itself (Fingelkurts and Fingelkurts 2004). In this context and following the logic of Clayton (2000, see also Section 6), there might be a room for divine influences in biological evolution.

Two different points of view have emerged from this brief review: one treats the religious experience as a by-product of human evolution and another explains the origin of religious experience as the result of the divine influences in biological evolution.

\section{Review of arguments}

This section does not provide a thorough review of research, but rather it simply presents an overview of the main arguments on whether our brain is hardwired to believe in and to produce God, or whether our brain is hardwired to perceive and experience God? It will become apparent that there are substantial theoretical disagreements between these two points of view.

\subsection{Arguments for the "producing" point of view}

A "producing" point of view (sometimes it is referred as neuroscientific and/or cognitive) is a reductionistic one and can be summarised as follows: our brain is structured so as to provide us with experiences that make us believe there is a God, but this belief may merely be the result of internal brain activity and our interpretation of it.

The followings are the main arguments for such position: 
Argument 1: It has been reported that the intense activation of the frontal and temporal cortices and limbic system, as well as (de)activation of the parietal cortex give rise to religious experience (for the full list of brain areas and structures and for the references, see Table 4).

Table 4. Summary of studies on the involvement/modulation/(de)activation of brain areas/structures during religious experience.

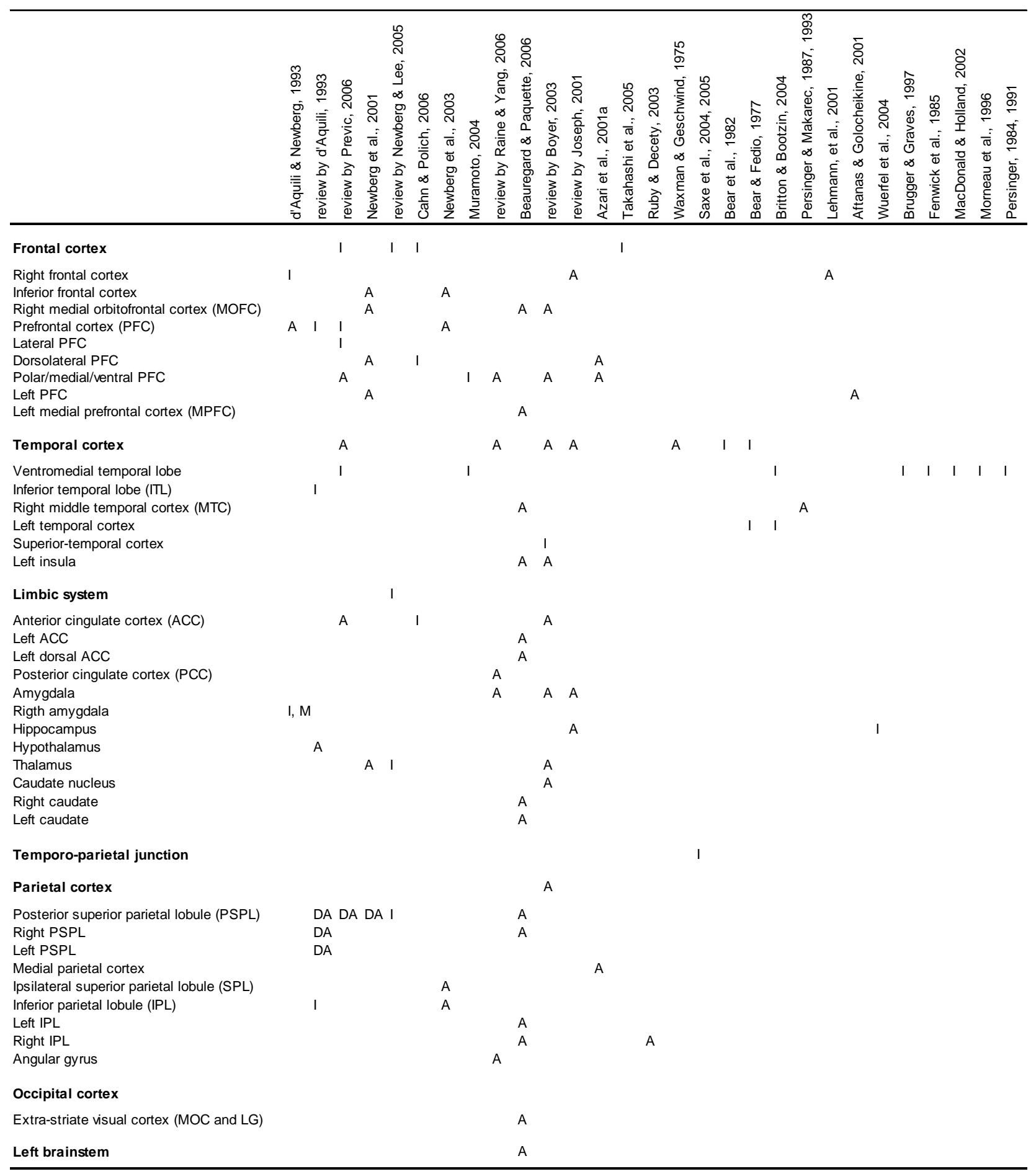

$\mathrm{I}=$ Involvement; $\mathrm{M}=$ modulation; $\mathrm{A}=$ activation; $\mathrm{DA}$ = deactivation 


\section{Comments:}

(a) As one can see, the list of brain areas and structures involved in religious experience is quite extensive. A probable explanation for this is that different researchers used different techniques and methods to induce a religious experience. Most results perhaps, reflect not a religious experience per se (which is more or less homogeneous, see above) but rather diverse phenomena such as: activity religious practice or execution of the ritual (meditation or prayer) and related cognitive activity; beliefs - reasoning about the truth of religious ideology; moral reasoning etc. A detailed and accurate inspection of the known functions of the brain areas and structures which have been reported to be involved/modulated/(de)activated during religious experience (Table 5) supports this position. 
Table 5. Summary of known functions of the brain areas which have been reported to be involved/modulated/(de)activated during religious experience.

\begin{tabular}{|c|c|c|}
\hline Brain areas & Functions & References \\
\hline Frontal cortex & $\begin{array}{l}\text { Plays a major role in attention, working memory, creative and critical thinking, planning, decision making, inhibitory } \\
\text { control and emotional regulation }\end{array}$ & $\begin{array}{l}\text { Shallice \& Evans, 1978; Stuss \& Benson, 1984; } \\
\text { Rueckert \& Grafman, 1996; Miotto et al., } 1996\end{array}$ \\
\hline Right frontal cortex & Is associated with the recall of affect-laden autobiographical memory & Calabrese et al., 1996; Fink et al., 1996 \\
\hline Inferior frontal cortex & $\begin{array}{l}\text { Controls the impact of distracting emotions on cognitive performance (left hemisphere) and the subjective feeling of } \\
\text { being distracted (right hemisphere) }\end{array}$ & Dolcos et al., 2006 \\
\hline $\begin{array}{l}\text { Right medial orbitofrontal } \\
\text { cortex (MOFC) }\end{array}$ & $\begin{array}{l}\text { Codes for subjective pleasantness of the taste or smell of stimuli or music; associated with ethical, social or } \\
\text { emotionally related behaviour; adaptation to complex changing environments; regulation of socio-emotional behaviour } \\
\text { in settings involving social affiliation and social judgment, self-awareness, inhibition, and the self-guidance of } \\
\text { behaviour through judgments and decisions about one's actions; exerts an inhibitory control to protect goal-directed } \\
\text { behaviour from interference; encodes the values that subjects assign to different items on a common value scale; }\end{array}$ & $\begin{array}{l}\text { Kringelbach et al., 2003; de Araujo et al., 2003; } \\
\text { Rolls et al., 2003; Blood \& Zatorre, 2001; Eslinger, } \\
\text { 1999; Bechara et al., 1994; Cummings, 1993; } \\
\text { Damasio, 1995; Damasio et al., 1990; Dolan, 1999; } \\
\text { Elliott, 1990; Fuster, 1997, 1999; Giancola and } \\
\text { Zeichner, 1994; Grafman et al., 1996; Grafman } \\
\text { and Litvan, 1999; Lapierre et al., 1995; Mesulam, } \\
\text { 1986; Zald and Kim, 1996; Roberts and Wallis, 2000; } \\
\text { Padoa-Schioppa \& Assad, } 2006\end{array}$ \\
\hline Prefrontal cortex (PFC) & $\begin{array}{l}\text { Responsible for selective attention to stimuli, perception of temporal contingent sequences, intention and will; } \\
\text { regulates negative affect and emotional distress; temporal organization of actions towards biological or cognitive goals; }\end{array}$ & $\begin{array}{l}\text { Beauregard, 2007; d'Aquili, 1993; Filley, 1995; } \\
\text { Godefroy et al., 1999; Badgaiyan, 2000; Collette \& } \\
\text { Van der Linden, 2002; Luria, 1966; Pribram, 1973; } \\
\text { Knight and Grabowecky, } 1995\end{array}$ \\
\hline Lateral PFC & $\begin{array}{l}\text { Supports processes related to the successful resolution of ambiguity in decision making; is involved in metacognitive/ } \\
\text { executive top-down processes, which refer to the ability to monitor and control the information processing necessary to } \\
\text { produce voluntary action; selection and control of behavioural strategies and action; the inhibition of inherent response } \\
\text { tendency; plays a crucial role in willed actions and with the holding in mind of information on which an action is to be } \\
\text { based; }\end{array}$ & $\begin{array}{l}\text { Flavell, 1979; Fuster, 1999; Damasio, 1995; } \\
\text { Frith and Dolan, 1996; Fuster, 1997; Goldman-Rakic, } \\
\text { 1987; Frith and Dolan, 1996; Fuster, 1999; Goldman- } \\
\text { Rakic, 1987; Roberts and Wallis, } 2000\end{array}$ \\
\hline Dorsolateral PFC & $\begin{array}{l}\text { Plays a profound role in sustaining reflexive evaluation of thought; reflects working memory expectation of the location } \\
\text { of the target; cognitive control; }\end{array}$ & Azari et al., 2001a; Watanabe, 1996 \\
\hline Polar/medial/ventral PFC & $\begin{array}{l}\text { Is activated in moral judgment tasks; is involved in the development of moral reasoning; is involed in moral decision- } \\
\text { making and in the regulation of moral emotions; plays a profound role in sustaining reflexive evaluation of thought; is } \\
\text { activated during self-referential judgments; is involved in monitoring performance }\end{array}$ & $\begin{array}{l}\text { review by Raine \& Yang, 2006; Azari et al., 2001a; } \\
\text { Gusnard et al., 2001; Kelley et al., 2002; } \\
\text { Ito et al., } 2003\end{array}$ \\
\hline Left PFC & $\begin{array}{l}\text { Helps to inhibit the negative emotions generated by limbic structures; reflect a domain-specific semantic working } \\
\text { memory capacity; guides controlled semantic retrieval; is involved in episodic encoding into long-term memory }\end{array}$ & $\begin{array}{l}\text { Gemar et al., 1996; Lane et al., 1997a,b; Gabrieli et } \\
\text { al.,1998; Wagner et al., 2001; Shallice et al., 1994; } \\
\text { Tulving et al., } 1994\end{array}$ \\
\hline $\begin{array}{l}\text { Left medial prefrontal } \\
\text { cortex (MPFC) }\end{array}$ & $\begin{array}{l}\text { Is linked with conscious awareness of feelings; involved in the metacognitive representation of one's own emotional } \\
\text { state; integration of the visceromotor aspects of emotional processing with information gathered from the internal and } \\
\text { external environments; is involved in the metacognitive representation of one's own emotional state; activated during } \\
\text { evaluation of statements with respect to people themselves and during moral judgments; plays a role in the ability to } \\
\text { attribute mental states to oneself or others in order to explain behaviour; involves monitoring or reporting one's own } \\
\text { mental state, such as self-generated thoughts, intended speech, and emotions; involved in attributing mental states to } \\
\text { others; is associated with explicit representations of states of the "self'; performs continuous "simulation of behaviour", } \\
\text { "an inner rehearsal" and "an optimization of cognitive and behavioural serial programs"; plays an important role in } \\
\text { conscious and voluntary regulation of emotion processes; }\end{array}$ & $\begin{array}{l}\text { Beauregard \& Paquette, 2006; Lane \& Nadel, 2000; } \\
\text { Beauregard, 2007; Johnson et al., 2002; } \\
\text { Greene et al., 2001; Castelli et al., 2000; Fletcher } \\
\text { et al., 1995; Gallagher et al., 2000; Lane et al., } \\
\text { 1997a,b; McGuire, et al., 1996a,b; Gusnard et al., } \\
\text { 2001; Pardo et al., 1993; Reiman et al., 1997; } \\
\text { George et al., 1996; Goel et al., 1998; } \\
\text { Frith \& Frith, 1999; Ingvar, 1985, 1991; }\end{array}$ \\
\hline Temporal cortex & Is involed in moral dilemmas; plays a role in "self-recognition" or "self-image"; store memories of life-events; & review by Raine \& Yang, 2006 \\
\hline Ventromedial temporal lobe & $\begin{array}{l}\text { Provides the action-extrapersonal system and mediates related extrapersonally dominated brain functions such } \\
\text { as dreaming and hallucinations; }\end{array}$ & review by Previc, 2006 \\
\hline Inferior temporal lobe (ITL) & $\begin{array}{l}\text { Attaches complex associations to the stimulus; alerting of the organism to the objects of interest or motivational } \\
\text { importance }\end{array}$ & review by d'Aquili, 1993 \\
\hline $\begin{array}{l}\text { Right middle temporal } \\
\text { cortex (MTC) }\end{array}$ & Is associated with learning and memory; & Adcock et al., 2006 \\
\hline Left temporal cortex & Contributes to the composition of sentence meaning & Vandenberghe et al., 2002 \\
\hline Superior-temporal cortex & Is the seat of spatial awareness; plays a role in auditory processing; subserves language processes & review by Karnath H-O, 2001 \\
\hline Left insula & Integrates representations of external sensory experience and internal somatic state & Augustine, 1996; Critchley et al., 2004 \\
\hline
\end{tabular}




\begin{tabular}{|c|c|c|}
\hline Brain areas & Functions & References \\
\hline \multicolumn{3}{|l|}{ Limbic system } \\
\hline $\begin{array}{l}\text { Anterior cingulate } \\
\text { cortex (ACC) }\end{array}$ & $\begin{array}{l}\text { Is involved in motivation control; monitors the consequences of actions; is involved in the regulation of autonomic } \\
\text { processes; encodes cognitive and emotional demands }\end{array}$ & $\begin{array}{l}\text { Ito et al., 2003; Luu \& Posner, 2003; } \\
\text { Davis et al., } 2005\end{array}$ \\
\hline Left ACC & Reflects goal-relevant control demand & Fincham \& Anderson, 2006 \\
\hline Left dorsal ACC & Reflects emotional awareness associated with the interoceptive detection of emotional signals; & Lane et al., 1997a,b, 1998 \\
\hline $\begin{array}{l}\text { Posterior cingulate } \\
\text { cortex (PCC) }\end{array}$ & $\begin{array}{l}\text { Is activated during moral judgment tasks; implicated in the processing of positive and negative emotionally; has } \\
\text { the evaluative functions which include the monitoring of sensory events and of the organism's own behaviour in the } \\
\text { service of spatial orientation and memory; is involved in visuospatial processing (orientation within and interpretation) } \\
\text { of the environment; is associated with the representation (monitoring) of the world around, and possibly within, us; }\end{array}$ & $\begin{array}{l}\text { review by Raine \& Yang, 2006; Maddock et al., } \\
\text { 2003; Maddock, 1999; Vogt et al., } 1992\end{array}$ \\
\hline Amygdala & $\begin{array}{l}\text { Is activated during moral judgment tasks; performs a primary role in the processing and memory of emotional reactions; } \\
\text { associates sensation with reward or punishment; }\end{array}$ & review by Raine \& Yang, 2006 \\
\hline Right amygdala & Is activated during the unconscious processing of emotionally (negative) expressive stimuli & Morris et al., 1999 \\
\hline Hippocampus & $\begin{array}{l}\text { Plays a role in memory and spatial navigation; and in the acquisition and recall of declarative memories and recalling } \\
\text { affect-related information; processes recent memory; }\end{array}$ & Eichenbaum, 2000; Markowitsch et al., 2003 \\
\hline Hypothalamus & Is the source of many of the most elemental emotions: hunger, thirst, chills, etc. -- ultimately pleasure \& pain & \\
\hline Thalamus & $\begin{array}{l}\text { Plays a critical role in perceptual processing; provides a behaviourally relevant, dynamic control over the nature of } \\
\text { information relayed, and also plays a key role in basic cortico-cortical communication }\end{array}$ & Sherman \& Guillery, 2005; Sherman, 2005 \\
\hline Caudate nucleus & $\begin{array}{l}\text { Is associated with positive emotions such as happiness, romantic love, and maternal love; active during reward-related } \\
\text { tasks and motivation-dependent responses }\end{array}$ & $\begin{array}{l}\text { Damasio et al., 2000; Bartels \& Zeki, 2000, 2004; } \\
\text { Delgado et al. 2000, } 2003\end{array}$ \\
\hline Right caudate & Is activated in the object working memory task & Levy et al., 1997 \\
\hline Left caudate & Is activated in the spatial working memory task; plays a universal role in monitoring and controlling the language in use & Lew et al., 1997; Crinion et al., 2006 \\
\hline Temporo-parietal junction & $\begin{array}{l}\text { Plays a critical role in false belief attribution; is involed in a semantic processing; and specifically in reasoning about } \\
\text { the contents of another person's mind }\end{array}$ & $\begin{array}{l}\text { Saxe et al., 2004; Saxe \& Wexler, 2005; } \\
\text { Saxe \& Kanwisher, } 2003\end{array}$ \\
\hline Parietal cortex & Is involved in the perception of spatial relations which are of a holistic or gestalt nature; stores long-term memory; & Newberg et al., 2001 \\
\hline $\begin{array}{l}\text { Posterior superior parietal } \\
\text { lobule (PSPL) }\end{array}$ & $\begin{array}{l}\text { Allows us to orient ourselves in space, that gives us a sense of boundary between ourselves and the rest of the world; } \\
\text { involved in higher order visual, auditory, somatosensory information; }\end{array}$ & Newberg et al., 2001; d'Aquili, 1993 \\
\hline Right PSPL & Is associated with the absence of a sense of self & Newberg et al., 2001 \\
\hline Left PSPL & Exerts influences in regard to objects that may be directly grasped and manipulated & Newberg \& d'Aquili, 2000; \\
\hline Medial parietal cortex & $\begin{array}{l}\text { Plays a profound role in sustaining reflexive evaluation of thought; in "perspectivity," bodily processes contributing to } \\
\text { ones point of view; in action planning; }\end{array}$ & Azari et al., 2001; Taylor, 2001; Ruby et al., 2002 \\
\hline $\begin{array}{l}\text { Ipsilateral superior parietal } \\
\text { lobule (SPL) }\end{array}$ & Is involved in the spatial perception of self; & Neggers et al., 2006 \\
\hline Inferior parietal lobule (IPL) & $\begin{array}{l}\text { Plays an important role in motor imagery; is responsible for generating abstract concepts and relating them to words; } \\
\text { is involved in conceptual comparison; }\end{array}$ & Decety, 1996; d'Aquili, 1993 \\
\hline Left IPL & Is implicated in the processing of visuospatial representation of bodies; & Felician et al., 2003 \\
\hline Right IPL & Is crucial in the process of self/other distinction; & Ruby \& Decety, 2003 \\
\hline Angular gyrus & $\begin{array}{l}\text { Activated in moral judgment tasks; in the level of abstractness/concreteness of 1st person reflection (personality traits } \\
\text { versus physical traits); pays role in "perspectivity," bodily processes contributing to ones point of view; in action; } \\
\text { planning; }\end{array}$ & $\begin{array}{l}\text { review by Raine \& Yang, 2006; Taylor, 2001; } \\
\text { Kjaer, et al., 2001; Ruby et al., } 2002\end{array}$ \\
\hline $\begin{array}{l}\text { Occipital cortex } \\
\text { Extra-striate visual cortex } \\
\text { (MOC and LG) }\end{array}$ & Is implicated in visual mental imagery & Ganis et al., 2004 \\
\hline Left brainstem & Maps the organism's internal state during emotion; & Damasio, 1999 \\
\hline
\end{tabular}

Even though the analysis of Table 4 has revealed that the prefrontal cortex (especially polar/medial/ventral prefrontal cortex) and temporal cortex (especially ventromedial temporal cortex) are more likely to be activated during religious experience, and the parietal cortex (especially posterior superior parietal lobule) is more likely to be deactivated during religious experience, there is no evidence whatsoever that specific brain regions or mechanisms are devoted to religious experience per se. If we draw on the schematic brain all brain areas or structures which have been ever reported to be involved in religious experience, then we can see that virtually all the brain is involved in (Fig. 1). 
A
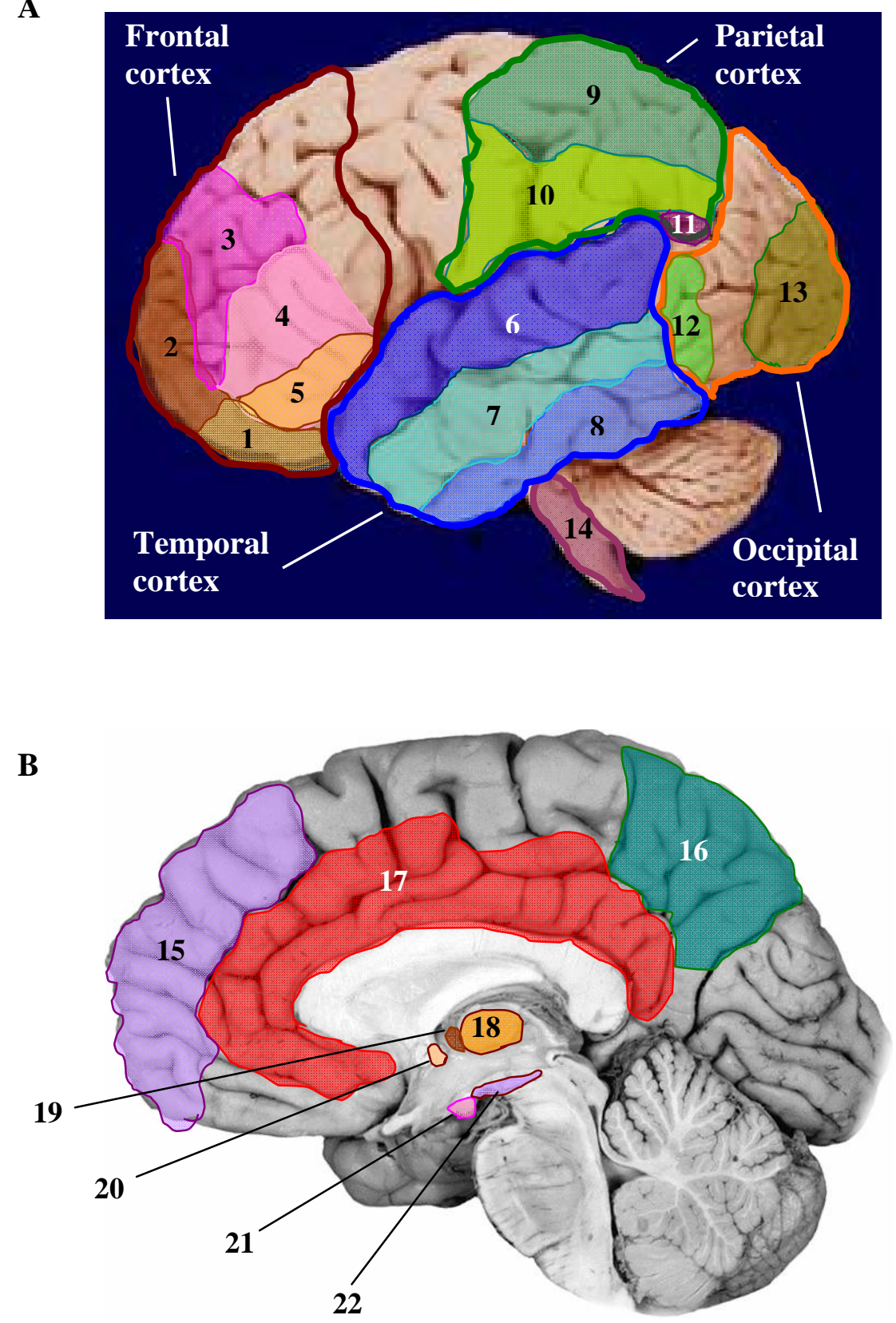

Figure 1. Schematic presentation of brain cortex areas and other structures which were reported to be involved/(de)activated during religious/spiritual/mystical experiences.

(A) Lateral surface. Frontal cortex (brawn outline): 1. Medial orbitofrontal cortex (MOFC); 2. Prefrontal cortex (PFC); 3. Dorsolateral PFC; 4. Ventrolateral PFC; 5. Inferior frontal cortex. Temporal cortex (blue outline): 6. Superior-temporal cortex; 7. Middle temporal cortex (MTC); 8. Inferior temporal lobe (ITL). Parietal cortex (green outline): 9. Posterior superior parietal lobule (PSPL); 10. Inferior parietal lobule (IPL); 11. Angular gyrus; 12. Temporo-parietal junction; 13. Occipital cortex (orange outline): Extra-striate visual cortex (MOC and LG). 14. Brainstem.

(B) Medial surface: 15. Medial prefrontal cortex (MPFC); 16. Medial parietal cortex, 17. Cingulate cortex (anterior and posterior); 18. Thalamus; 19. Hypothalamus; 20. Caudate nucleus; 21. Amygdala; 22. Hyppocampus.

Not shown: Ventromedial temporal lobe and insula. 
Thus, religious experience does not involve a specific neural system and probably requires joint activation of a family of systems each of which is usually involved in non-religious contexts. This conclusion is in line with the work of Azari et al. (2001b). It is also consistent with the work of Fingelkurts and Fingelkurts $(2001,2005,2006)$ who advocate that phenomenal experiences are reflected in meta-stable patterns of neuronal interconnectivity among brain areas and systems.

(b) The formulation of argument (1) is weak because the findings on which it is based are correlative in nature, and as such, they tell us nothing about the cause-consequence relationships. Thus, if brain activity changes during religious experience, it is not clear whether the brain activity caused that experience or responded to that experience (Newberg and Lee 2005).

Argument 2: The right hemisphere is involved more than the left in the reception and production of religious experience (for the references, see Table 6). For known functions of the brain hemispheres see Table 7.

Table 6. Survey of brain laterality during religious experience.

\begin{tabular}{|c|c|c|c|}
\hline References & $\begin{array}{l}\text { Involvement/ } \\
\text { dominance } \\
\text { of the RIGHT } \\
\text { hemisphere }\end{array}$ & $\begin{array}{l}\text { Involvement/ } \\
\text { dominance } \\
\text { of the LEFT } \\
\text { hemisphere }\end{array}$ & $\begin{array}{l}\text { NO } \\
\text { laterality }\end{array}$ \\
\hline Runehov, 2004 & + & & \\
\hline Fenwick, 1987 & + & & \\
\hline Ehrlichman \& Wiener, 1980 & + & & \\
\hline West, 1987 & + & & \\
\hline Ornstein, 1972 & + & & \\
\hline Persinger, 1993 & + & & \\
\hline d'Aquili \& Newberg, 1993 & + & & \\
\hline review by Joseph, 2001 & + & & \\
\hline Lehmann, et al., 2001 & + & & \\
\hline Persinger \& Makarec, 1987 & + & & \\
\hline Persinger, 1993 & + & & \\
\hline Ruby \& Decety, 2003 & + & & \\
\hline review by d'Aquili, 1993 & + & + & \\
\hline Newberg et al., 2001 & + & + & \\
\hline review by Boyer, 2003 & + & + & \\
\hline Beauregard \& Paquette, 2006 & + & + & \\
\hline Bear \& Fedio, 1977 & & + & \\
\hline Aftanas \& Golocheikine, 2001 & & + & \\
\hline Kohlmetz et al., 2003 & & + & \\
\hline Britton \& Bootzin, 2004 & & + & \\
\hline Gazzaniga, 2005 & & + & \\
\hline Bennett \& Trinder, 1977 & & & + \\
\hline Pagano \& Warrenburg, 1983 & & & + \\
\hline Schuman, 1980 & & & + \\
\hline
\end{tabular}


Table 7. Known functions of the brain hemispheres.

\begin{tabular}{|c|c|c|}
\hline Brain hemispheres & Functions & References \\
\hline $\begin{array}{l}\text { Left-hemisferic (LH) } \\
\text { predominance }\end{array}$ & $\begin{array}{l}\text { The prepositional, verbal left hemisphere associates with the rational "I"; contributes to dreaming and some } \\
\text { hallucinations; creates beliefs; is connected to verbal material, signs, symbols, and writing stereotypes, all of which } \\
\text { provide verbal communication; contains metrical space of visual images organized as their "alphabet" equally in } \\
\text { different people; built isolated elements of integrative structures of the human activity; has the consecutive analysis of } \\
\text { information, whether verbal or nonverbal }\end{array}$ & $\begin{array}{l}\text { review by Previc, 2006; Fischer, 1971; } \\
\text { Gazzaniga, 2005; Sperry et al., 1969; } \\
\text { Gazzaniga, 1970; Nevskaja \& } \\
\text { Leushina, 1990; Gribov, 1988; 1992; } \\
\text { Gordon, } 1978\end{array}$ \\
\hline $\begin{array}{l}\text { Right-hemisferic }(\mathrm{RH}) \\
\text { predominance }\end{array}$ & $\begin{array}{l}\text { The intuitive non-verbal right hemisphere associates with the "self'; easier than the LH, elaborates associations } \\
\text { between images of different objects, differentiated by the exterior form or by the structure; is connected to nonverbal } \\
\text { material, namely: perception of nonverbal images; melodies, intonations; space and body position orientation; visual } \\
\text { field dependence; identification of complicated patterns (such as human faces); performance of kinesthetic functions } \\
\text { etc; stores the characteristics of complete images - comparison standards, and retains individual structural information } \\
\text { on them; integrats isolated elements - connects them into adequate "right now" working configurations; simultaneously } \\
\text { processes of many elements of information }\end{array}$ & $\begin{array}{l}\text { Fischer, 1971; Gazzaniga, 1970; Levy \& } \\
\text { Trevarthen, 1976; Sperry et al., 1969 } \\
\text { Nevskaja \& Leushina, 1990; Gribov, 1988; } \\
\text { 1992; Gordon, } 1978\end{array}$ \\
\hline
\end{tabular}

\section{Comments:}

A detailed analysis of the literature available (see Table 4) has revealed no consistent interhemisphere prevalence of one particular brain area during religious experience. This is consistent with the comments on argument (1). Taken together, our commentary on arguments (1) and (2) indicate that religious experience is not determined by but rather is accompanied by changes in particular brain areas and systems depending on the practice and situation which give rise to this experience.

Argument 3: Electrical brain activity is altered during religious experience: research has shown large amounts of high amplitude alpha and theta waves ${ }^{14}$ during the religious experience especially in the prefrontal and parietal areas (Corby 1978; Lobusov et al. 2001; Takahashi et al. 2005; for the review, see Cahn and Polich 2006). Moreover, increased alpha-theta range coherence ${ }^{15}$ among recording sites has been observed intra- and inter-hemispherically during religious experience (Dillbeck and Bronson 1981; Badawi et al. 1984; Gaylord et al. 1989; Travis and Wallace 1999; Aftanas and Golocheikine 2001; Travis 2001; Faber et al. 2004; Hebert et al. 2005).

\section{Comments:}

In spite of almost 50 years of electroencephalographic (EEG) studies of religious experience, no clear consensus about the underlying neurophysiologic substratum of religious experience has emerged. Also see the last comment for the argument (1).

\footnotetext{
${ }^{14}$ Alpha (the frequency range of $8-12 \mathrm{~Hz}$ ) and theta (the frequency range of 4-8 Hz) waves are electromagnetic oscillations arising from synchronous and coherent (in phase) electrical activity in the human brain.

${ }^{15}$ Coherence is a measure of the dependence of two random variables.
} 
Argument 4: Chronic hyper-stimulation of particular brain areas can induce an individual to become hyper-religious or visualise and experience a divine being (Makarec and Persinger 1985; for the review, see Joseph 2001).

\section{Comments:}

This argument lacks an explanation why such stimulation should necessary induce religious experience. To our knowledge stimulation of brain areas may evoke experiences with different contents (not necessary religious) as well as brief flashes of previous ordinary experience (Jasper and Penfield 1954).

Argument 5: Often religious experience is a manifestation of such psychopathological disorders as temporal-lobe epilepsy, schizophrenia, bipolar disorder and obsessive-compulsive-disorder (for the references, see Table 1).

\section{Comments:}

There is enough evidence to rule out psychopathology as an adequate explanation of religious experience (Mandell 1980; Wright 1989). See Section 5 for a clear distinction between spiritual pathology and non-pathological religious experience.

Argument 6: It has been reported that activation or deactivation of the neuromediator's systems of the brain such as the dopaminergic, acetylcholinergic, serotoninergic, glutamatergic, and opioid systems gives rise to religious experience (for the references, see Tables 2,8). The known functions of neuromediator's systems of the brain can be found in Table 3 .

Table 8. Neurochemestry and religious experience.

\begin{tabular}{lllll}
\hline & $\begin{array}{l}\text { Dopaminergic } \\
\text { system }\end{array}$ & $\begin{array}{l}\text { Serotonergic } \\
\text { system }\end{array}$ & $\begin{array}{l}\text { Acetylcholinergic } \\
\text { system }\end{array}$ & $\begin{array}{l}\text { Opioid } \\
\text { system }\end{array}$ \\
\hline Kjaer et al., 2002 & A & & \\
Comings et al., 2000 & A & & \\
Krummenacher et al., 2002 & A & & \\
Shaner, 1999 & A & DA & \\
Previc, 2006 & A & DA & \\
Borg et al., 2003 & & DA & A, DA \\
Fallon et al., 1990 & & & A, DA & \\
Perry \& Perry, 1995 & & & & I \\
Sarter \& Bruno, 1998 & & & \\
Roth et al., 2002 & & & \\
\hline
\end{tabular}

$\mathrm{I}=$ Involvement; $\mathrm{A}=$ activation; $\mathrm{DA}=$ deactivation 


\section{Comments:}

It seems that all the main neuromediator's systems in the brain are involved (except the noradrenalinergic system) in religious experience. It means that religious experience does not involve a specific neuromediator's system and probably requires joint activation of a family of systems each of which is usually involved in non-religious contexts.

Argument 7: Several psychotropic drugs (for a list of drugs and references, see Table 2) can lead to religious experience.

\section{Comments:}

There is enough evidence to rule out psychopharmacology as an adequate explanation for religious experience. See Section 5 for a clear distinction between pharmacologically induced spirituality and non-pharmacological religious experience.

Argument 8: Religious experience is just the brain's interpretation of its own residual or random activity (d'Aquli 1993; Sperber 1996; Boyer 2001). In another words, inadequate activation of different brain areas or structures causes different and unusual sensations and consequently unusual experiences. The failure to anchor these perceptions with feedback from the external world can lead to bizarre consequences which are interpreted as religious experience.

\section{Comments:}

This is the most common and 'favourite' argument used by neuroscientists. In our opinion this argument is weak for the following reasons:

Why should the interpretation be of a religious nature in the first place?

(a) For example, similar or the same unusual (bizarre) ${ }^{16}$ experiences in the dreams are very rarely interpreted as being of a religious nature. On the contrary, they are considered natural and without any religious content.

Indeed, a content analysis of 16,000 reports of dreams (Krippner et al. 2001) demonstrated that religious and spiritual elements are generally extremely infrequent in dreams: only up to $2 \%$ of the dreams reports mentioned religious places, denominations, concepts or objects. At the same time, bizarre elements occurred in the dreams much more often than religious and spiritual elements. Thus, content analysis of dreams revealed $14-84.2 \%$ occurrence for bizarre elements in dreams (Rechtschaffen et al. 1963a,b; Cicogna et al. 1998; Kahn et al. 2000).

\footnotetext{
${ }^{16}$ Bizarre objects/actions/persons etc. are defined as not existing or as impossible in waking-life reality (States, 2000)
} 
Thus, the significant difference in the occurrence of religious (up to $2 \%$ ) and bizarre (up to $84 \%$ ) elements in the dreams suggest that bizarre elements in dreams are not usually interpreted by the brain as religious. Therefore, similarly bizarre experiences in an awake state should not be necessarily interpreted by the brain as religious.

(b) There are many experiences that are epistemologically similar to religious experience but nevertheless they do not give rise to religious interpretations. As one example let us look at extrovertive experiences (Marshall 2005). Like religious experience it tends to be characterised by one or more of the following: profound sense of unity, profound sense of knowledge or profound sense of contact with reality. However, this experience is distinguished from religious experience by its orientation towards the natural world. In extrovertive experience, such features as unity, knowledge, reality, love, luminosity and so forth, characterize experience of the natural world, but not the experience of something beyond the natural world such as a transcendent God, soul, or divine realm.

Comments (a) and (b) lead one to the conclusion that "interpretation argument" for explanation of religious experience should not be considered as the main one.

Argument 9: Fischer (1971) argues that religious experience results simply from the loss of cortical "freedom" to interpret subcortical activity.

\section{Comments:}

It is well known that subcortical activity in animals contributes to behaviour to a larger extend than in the humans. Considering this fact and Fischer's argument, one would expect much more religious experience and behaviour in animals. However, we do not have any evidence of religious experience or behaviour in animals (see also Rolston 2005).

Argument 10: Proudfoot (1985) claims that religious experience is not a result of "direct perception," because interpretation plays a role in it. For Proudfoot, religious experience is shaped by doctrine and belief. He argues that religious experience arises only through our cultural contexts. This is in line with the view of Wuthnow (1992). Proudfoot suggests that without religious language one could not have a religious experience (Proudfoot 1985). Thus, he posits that there is no experience that is prior to language.

\section{Comments:}

Even though cultural contexts do affect individual experiences, concerning religious experience this position fails to consider seriously the following: 
(a) Why should the interpretation be exclusively of a religious nature? Within the same culture and religious doctrine such experiences (which are epistemologically similar to religious experience) as bizarre experience in the dreams and extrovertive experience (see above) are not interpreted as religious.

(b) Within the same culture and religious doctrine (i) not all religious persons claim to have had religious experiences (Saver and Rabin 1997); (ii) non-religious persons (atheists) have reported having religious experiences (Hood et al. 1996; Robinson 2000); (iii) religious experience may also arise spontaneously in the most prosaic of circumstances, outside any tradition of religious doctrine and practice; (iv) despite the fact that vast majority of people were raised and educated in absolutely atheistic environment in Soviet Union (which lasted 70 years), many people still had a religious experience (Katz 1971).

"Cultural interpretation" position also fails to account for empirical evidence indicating that:

(a) There is a genetic contribution to the tendency of a human to have a religious experience (Waller et al. 1990; D’Onofrio et al. 1999a,b; Eaves et al. 1990; Eaves 2004) and genetic variation contributes up to $50 \%$ of individual variation in religiosity (Bouchard et al. 1990);

(b) Young children whose parents are atheists may have religious experience (Evans 2000, 2001) and their religiosity may persist without any specific or robust cultural input (Kelemen 2004; Kelemen et al. 2005);

(c) If we consider the individual's first religious experience, then it is difficult to find something in the individual's past non-religious experience what can directly serves as an explanatory model;

(d) Available (but limited) data (see above) suggests that religious experience appeared almost simultaneously with such pre-cultural phenomena as language, drawings and rituals (Logan 2006). However, it is much earlier the time when culture starts to exert its own strong influence on the way the individual perceives his/her environment and shapes his/her experience.

In the light of these deficiencies, the "cultural interpretation" position suffers from limited phenomenological adequacy. Thus, one can conclude that ones own religious experience is most likely not an interpretation conditioned by cultural/environmental pressure.

Considering the comments on arguments (8), (9) and (10) the "interpretation argument" should not be included as the main explanation of religious experience.

Argument 11: Religious experience is a by-product of ordinary cognitive functions (Boyer 2001, 2003). 


\section{Comments:}

(a) All basic cognitive functions of humans (perception, attention, memory and others) are the same (or are analogous) in non-human animals (Baars 2005; Watanabe and Huber 2006). Moreover, several cognitive universals are common for humans and animals (Norenzayan and Heine 2005). These cognitive universals are: (i) quantity estimation - it does not require culturally invented counting systems, it appears in early infancy, and it is shared by other non-linguistic higher primates; (ii) the exposure effect, or the tendency to experience increased positive affect towards familiar objects relative to unfamiliar ones - this robust affective phenomenon can emerge without any conscious awareness, it is impervious to reasoning processes, and it is evident across species; (iii) social facilitation, or the finding that the presence of others can facilitate performance of a dominant (well-learned) behaviour and inhibit performance of a nondominant (poorly learned) behaviour - this effect is mediated by physiological arousal and occurs widely in the animal kingdom.

Considering these facts and explanation of religious experience as a by-product of ordinary cognitive functions one should conclude that animals should have a religious experience too. However, we do not have any evidence of religious experience or activity in animals (see also Rolston 2005).

(b) It may be the case that 'religious representations' are not acquired in quite the way Boyer claims. It may turn out that the religious concepts that Boyer describes as 'acquired' are essentially innate. Recall innate intuitive theism of young children (see Section 4).

Thus, the "by-product argument" cannot be considered as the principal explanation of religious experience. However, complex cognitive processes are most likely involved in religious experience (Newberg et al. 2001a,b; Azari and Birnbacher 2004) in the same way as they are involved in any other subjective experience.

Argument 12: As cognitive mechanisms that support religious (as well as any other) experience are error-prone, they cannot be trusted to give us Truth (Boyer 2001; Atran 2002). As we cannot trust these aspects of our minds to give us Truth, we cannot trust most of our religious experience.

\section{Comments:}

The treatment of this argument we borrow from Barrett (2007): "The cognitive sciences have given us evidence that our minds - for the sake of survival - can be systematically fallible, trading survival and reproduction for accurate representations of reality. On what basis then do we trust our minds at all? Our minds cannot be trusted to tell us that gods exist, that other human minds exist, 
that our memories are reliable, or that natural laws remain the same from moment to moment, or that cognitive science can produce accurate findings or that evolution is true. The Error-Prone Mind argument proves to be self-defeating - it has a Suicidal Tendency" (for detail treatment, see Barrett 2007).

Argument 13: People's actual religious concepts often diverge from what they believe they believe (Barrett and Keil 1996).

\section{Comments:}

Religious concepts and beliefs should be distinguished from religious experience (see Section 2). Several pieces of evidence support this position: (a) Non-religious persons have reported having religious experiences (Hood et al. 1996; Robinson 2000); (b) church attendance has proven to be unrelated to religious experience (Makarec and Persinger 1985) and finally (c) not all religious persons actually claim to have had religious experiences (Saver and Rabin 1997).

Argument 14: One of the main reasons for the existence of religious experience is innate people's search for causal explanations and organizing the world in a meaningful and consistent fashion to impose order and predictability on it.

\section{Comments:}

Because the same reasons also apply to scientific work, the explanatory power of this statement for religious experience is weak.

Argument 15: Viewed objectively and dispassionately, personal experience of God does not constitute appropriate scientific evidence of God's presence or existence.

\section{Comments:}

We agree with this argument. However, we would like to mention that realities that are independent of human existence but not embodied in physical form do exist (Ellis 2001): at least part of mathematics (e.g. prime numbers, Gödel's incompleteness theorem) was discovered, not invented.

\subsubsection{Concluding remarks}

It follows from this brief critical review of the arguments for a "producing" point of view that observed neuroscientific arguments tell us nothing about the true nature of religious experience or God. The reviewed results of neuroscience neither prove a "producing" point of view nor disprove a "perceiving" point of view. Therefore, the only conclusion from observed neuroscientific studies is that religious experience is reflected in brain activity and that the brain somehow mediates some aspects of religiosity. 
Additionally, neuroscience may eventually help researchers to explain the human ability to express and understand God.

\subsection{Arguments for a "perceiving” point of view}

The "perceiving" position (sometimes it is referred as theological) can be summarised as follows: our brains have the capacity to perceive God, and since our brain is designed to attune us to reality, this points to the likelihood that there is a God.

The followings are the main arguments for this position:

Argument 1: If the human brain enables humans to have religious experience, to perceive and believe in God, then it should be a reason for this experience (Joseph 2001).

\section{Comments:}

Religious experience may co-evolve with any other human phenomenon (for example, DA-mediated abstract reasoning, Previc 2006) which increases the survival of the organism. On the other hand, religious experience and practice themselves may have a protective effect on human communities and thus may also increase their survival (see Section 7).

However, this reasoning tries to explain how religious experience has been preserved in human evolution but not the reason for the origin of religious experience. Clayton (2006) speculates that human perhaps have religious experience because we live in a universe that is open to transcendence, a universe that is the product of a cosmic order. Indeed, studies of modern primitive tribes have shown that it is not a reflection and not a philosophy that drove the first people, but irrational intuition: they saw world full of spirits not because they thought about this world and tried to interpret it, but because they perceived mysticism in nature (Menn 1997).

Argument 2: Religious experience in the general population is negatively associated with psychoticism, depression and other illness (Batson and Ventis 1982; Francis and Wilcox 1996; Maltby 1997; Roman and Lester 1999). Additionally, there does not appear to be a positive correlation between psychosis among religious practitioners in general (Spencer 1975).

\section{Comments:}

This argument stresses that religious experience in the vast majority of individuals is associated with non-pathological brain activity.

Argument 3: There is no evidence that specific brain regions or mechanisms are devoted to religious activity per se (see Section 8.1., comments for the argument (1)). 


\section{Comments:}

This means that religious experience cannot be reduced solely to particular brain activity.

Argument 4: A religious experience is invariably perceived as being more real than the baseline reality of everyday life (for a discussion of this issue, see Newberg and Lee 2005).

\section{Comments:}

This means that religious experience should be distinguished from other altered states of consciousness such as dreams, drug-induced states or psychotic hallucinations with religious content.

Argument 5: Having consciousness (as an emergent property of a complex neurophysiological system; Revonsuo 1995, 2001) humans exercise a form of causation distinctive from physics: conscious agency which can be described by means of 'circular causality' (Varela and Thompson 2003).

\section{Comments:}

Indeed, humans are driven not only by survival and reproduction but also by complex sets of insights, goals and beliefs (Beauregard 2007). According to Clayton (2000) conscious agency would in principle allow God to influence human thoughts and motives at the same mental level that other persons influence them.

Argument 6: The mental level is dependent on, yet not reducible to, the physical level. In other words, there are mental causes that are not themselves a direct product of physical causes (Clayton 1999).

\section{Comments:}

This means that (a) mental level represents a type of property, not a new form of substance, (b) mental causation does not involve the addition of new energy into physical systems, and (c) mental causation is not supernatural, it is natural (see Clayton 1999).

Argument 7: A recent review of neuroimaging studies (Beauregard 2007) has demonstrated that mental causation does exist: (a) The results of neuroimaging studies into the conscious and voluntary regulation of various emotional states (sexual arousal, sadness, negative emotion) show that metacognition and cognitive recontextualisation selectively alter the way the brain processes and reacts to emotional stimuli; (b) The results of neuroimaging studies into the effect of psychotherapy in patients suffering from diverse forms of psychopathology (obsessive-compulsive disorder, panic disorder, unipolar major depressive disorder, social phobia, arachnophobia, borderline personality) indicate that the mental functions and processes involved in diverse forms of psychotherapy exert a significant influence on brain activity; (c) The results of neuroimaging investigations into the 
placebo (Beauregard 2007) and nocebo ${ }^{17}$ (Dworkin et al. 1983; for the review, see Benedetti et al. 2007) effects in healthy individuals (placebo analgesia ${ }^{18}$, psychostimulant expectation) and patients with Parkinson's disease or unipolar major depressive disorder demonstrate that beliefs and expectations can markedly modulate neurophysiological and neurochemical activity in brain regions involved in perception, movement, pain and various aspects of emotion processing.

For a review on mind-mind interaction effects and resent results, see the work of Wackermann (2004 and also see Seiter 2002); for mind-matter interaction, see Radin and Nelson (2002).

Comments:

Collectively, these findings strongly support the view that (a) the subjective nature and the intentional content (a first-person perspective) of mental processes (e.g., thoughts, feelings, beliefs and volition) are neither identical with nor fully reducible to brain processes; (b) that mental processes or events do exert "downward" causal influence on brain plasticity and the various levels of brain functioning (e.g., molecular, cellular and neural circuit) (Varela and Thompson 2003; Beauregard 2007; Benedetti et al. 2007); (c) mind-matter interaction and mind-mind interaction effects may exist (Wackermann 2004; Radin and Nelson 2002; need to be reproduced and investigated further). However, mental processing does not occur without concurrent physical activity in the brain.

Argument 8: There are evidences that the religious experience, religiousness and prayer are positively correlated with health (mental and physical) and self-actualisation (Byrd 1988; Kune et al. 1993; Matthews et al. 2000; Cha et al. 2001; Abdel-Khalek and Lester 2007; Liebovici 2001; for the reviews, see Braam et al. 2001; Koenig and Cohen 2002; Koenig et al. 2001; Marks 2005).

\section{Comments:}

Perhaps the religious experience offers some protection ("downward" causal influence) against certain types of mental and physical illness what provides additional support to the previous comments relating to argument (7).

\footnotetext{
${ }^{17}$ The nocebo effect is a phenomenon that is opposite to the placebo effect, whereby expectation of a negative outcome may lead to the worsening of a symptom.

${ }^{18}$ Analgesia is a loss of sensation of pain
} 


\subsubsection{Concluding remarks}

It follows from this brief critical review of the arguments for the "perceiving" point of view that evolution managed to evolve an organ - the brain - capable not only of reflecting on itself but of experiencing something higher than itself (see Newberg et al. 2001a,b). This became possible due to the emergence of a form of causation distinctive from physics: mental/conscious agency which (a) is neither identical with nor reducible to brain processes, (b) which exerts "downward" causal influence on brain plasticity and the various levels of brain functioning. However, the presented review while not proving a "perceiving" point of view not disproves it either.

To progress further one needs to overcome conceptualisation problem and to establish methodologically adequate research program.

\section{The problem of conceptualisation}

As it follows from critical review of the arguments for both the "producing" and "perceiving" points of view the main empirical question "Is our brain hardwired to believe in and produce God, or is our brain hardwired to perceive God?" remains unanswered. Indeed, the previous two sub-sections have shown that both points of view on Brain-God problem are legitimate. Each offers some insight regarding this issue. However, neither one, by itself, simultaneously takes into account both sides (e.g., BrainGod), as they are unified in subjective experience (and brain processes that support it). Therefore, we argue that neither description, in isolation, is satisfactory. It seems that at least a part of the problem is based on wrongly chosen levels of description and explanation. We believe that the appropriate level should articulate integration of subjective experience, cognitive processes, and large-scale brain activity which relates to phenomenological level of subjective experience (Wildman and Brothers 1999; Fingelkurts and Fingelkurts 2001, 2005; Fingelkurts et al. 2009).

As is apparent from the previous sections, the problem of conceptualisation arises when researchers attempt to reduce religious experience solely to brain activity based on a misinterpretation of their own results. It is implicitly or explicitly assumed in such attempts that religious experience is a byproduct of brain or cognitive processes. Theologians, on the other hand, often reject the importance and relevance of biology for explanation of religious experience. We do not agree with these views for several reasons (based on the reviews presented in the previous sections). 
First, religious experience (a) is a real, natural, normal, world-wide, universal among cultures, permanent in human history, heritable (but not inherited) phenomenon, (b) is reflected in (or even partially instantiated by) brain activity, and (c) exists in all stages of individual development (from infancy through adolescence and into adulthood). Second, religious experience (a) does not depend directly on the brain anatomy or specific brain regions, on culture and environment, (b) is not the outcome of psychopathology or psychopharmacology, (c) is not a brain interpretation of its own states, and (d) is not a (sub)cortical activity or by-product of ordinary cognitive functions.

Moreover, religious experience exists only in humans (there are no any evidences of religious experience or activity in animals whatsoever) (see also Rolston 2005). At the same time, only humans have developed a form of causation distinctive from physics: conscious agency (see above). This means that humans are driven not only by survival and reproduction but also by complex sets of insights, motives, intentions, thoughts and beliefs. These mental processes and events do exert a "downward" causal influence on physical processes (brain plasticity and the various levels of brain functioning) but are not themselves a direct product of physical causes. This would in principle allow divine influences on human thoughts and motives at the same mental level that other persons influence them.

Generalising about the data described in this paper, it should be suggested that the potential for religious experience is an innate biological characteristic. Development of this characteristic is a biosocial issue, and the realisation of religious experience is a psychobiological issue. Thus, all this makes it suitable for "bridging" biology and theology to describe and later to explain religious experience.

Each of the descriptions of religious experience has usually been tackled separately, not simultaneously by the researchers. This is inherently implausible and requires significant oversimplification. What emerges in the human case is a particular psychosomatic unity, an organism that is capable of both mental and physical things (Clayton 1999). Therefore, an understanding of human nature in its unity (not just as a mixture of brain/body/matter and consciousness $/ \mathrm{mind} / \mathrm{spirit}$ ) is of scientific and theological importance. Thus, perhaps the most promising research framework for the investigation of religious experience is an integrated one (within a single experimental study) that utilizes the reality of the multiple levels and dimensions of human existence (physical, biological, psychological and spiritual reality), allowing consciousness/mind/spirit and brain/body/matter to be seen as different sides of the same phenomenon, neither reducible to each other. Such a general theoretical framework may allow researchers to handle in a plausible manner an enormous amount of diverse observations related to the brain, mind and spiritual phenomena. 


\section{Integration of theological and neuroscientific points of view}

Theological and neuroscientific views are two quite different ways of looking at and describing the world, and at first glance, there is no direct link or correspondence between them. This apparent barrier can only be traversed by developing an explanatory common framework (or reference). This requires an explanation using phenomena within the same conceptual continuum. In our opinion such a common conceptual framework could be found ${ }^{19}$.

Let us start with a theological point of view.

Starting from ancient Egyptians (Fergus and Lothian 1997), early pre-Pythagoreans (Rohde 1925), Epicureans and Stoics, and also by Plato, Aristotle and Plotinus (King 2005) the body and soul were considered as complimentary parts of the same unified whole entity ${ }^{20}$, - living human being (Klima 1984; King 2005). In Judaism (Youde 2003), Christianity (including present Christian Catechism $^{21}$ ) and Islam (Muhammad Ali 2002) the human being is understood as a unified trinity of Spirit (God's breath), soul and flash/matter. From this trinity at least one ingredient - human matter (brain) - is obviously a natural/objective phenomenon in the physical world which has a biological nature; therefore it can be (and is) readily studied scientifically within neuroscience and has been given the least attention in theological literature. On the contrary, Spirit and soul are not at all scientific concepts, - their origins lie in a theological point of view.

Theology assumes that Spirit is not the reality of the physical universe, but rather is the reality of freedom, it is the world-for-itself. It is not an object, and therefore the reality of Spirit is not the reality of objects. Hence, theology concludes that in the physical universe there is no such object and/or objective reality which we could call Spirit (Berdyaev 1937). That seems to be a fundamental mystery. In the light of the above considerations, it is obvious that Spirit (as an ingredient of the human being) is inexplicable within the scientific paradigm, but nevertheless it can be perceived and cognised through the process of objectification when the Spirit is revealed in the subject ${ }^{22}$.

\footnotetext{
${ }^{19}$ However, we understand and accept that there may be some aspects of the relationship between spiritual (Divine) and brain (Physical) natures that will escape our understanding forever, but that should not stop us from trying still to understand it.

20 Even though in the main stream Buddhism, Hinduism, Jainism and Chinese religious tradition there is similar understanding of body and soul interaction, generally these traditions contain many variant and inconsistent beliefs on the origin, purpose, and fate of the soul.

${ }^{21}$ A catechism is a summary or exposition of doctrine, traditionally used in Christian religious teaching from New Testament times to the present.

${ }^{22}$ In the other words, 'ideal' (as a subjective form) get realised in the matter as 'real' objective form.
} 
In further discussion we will use the Genesis text as common scripture for three world religions (Judaism, Christianity and Islam). Considering the description in Genesis ${ }^{23}$ (2:7), the following formula can be suggested (Gijsbers 2003): Body + God's breath (Spirit) = Living soul. Thus, the soul is the product of the Spirit-body interaction: Somehow, these two natures, although seemingly worlds apart, must be intimately connected. The human brain is that specific location in the physical universe where divine enters the human through a Spirit (Menn 1999) and manifests itself as a soul. More specifically, certain arrangements of physical matter in the brain (which have occurred in the course of evolution and ontogenesis) together with the Spirit (which is God's breath) cause the coming into being of something different - conscious soul.

Soul, according to majority of religious and philosophical traditions, is the self-aware essence unique to a particular human being, the unification of one's sense of identity, so called subjective worldfor-someone. Ancient Greeks typically referred to the soul as psyche (Bremmer 1983), while ancient Muslim philosophers Avicenna and Ibn al-Nafis described the soul as a human self-awareness (Hossein Nasr and Leaman 1996). Buddhists also relate the ever-changing entity - mind or principle of "anatta" with the cause of continuity of the human consciousness (Conze 1993). Hinduists and Jainists consider soul as either personality ("Jiva/Atman"), consciousness ("Jiva/Cetana") or knowledge/perception ("upoyoga"). Most Christians regard the soul as the seat or locus of human will, understanding and personality. In the same vein Richard Swinburne, a Christian philosopher of religion at Oxford University, states that soul is the subject of mental properties: it has sensations and thoughts, desires and beliefs, and performs intentional actions (Swinburne 1986). Indeed, the detail analysis of Western and Non-Western traditions (for the review, see Carter 2000) demonstrated that universally, and for as far back as we can trace (starting from the Hebraic and Greek terms), soul and consciousness have been closely associated ${ }^{24}$.

Therefore, the 'soul' as it has been described formally from a theological point of view is the very same and precise description of the human mind with its consciousness as defined in cognitive neuroscience (and related scientific fields): Mind refers to the collective aspects of intellect and consciousness which are manifest in some combination of thought, perception, emotion, will and imagination. It is this subjective world-for-someone which would not have existed if this someone

\footnotetext{
${ }^{23}$ Genesis is the first book of the Bible used by Judaism and Christianity and to a large extend in Qur'an. It contains stories about the creation of the world and human being.

${ }^{24}$ Note that sometime the notions of "soul" and "Spirit" are used as synonyms. This may bring confusion and consequently may lead to a debate in the history of religions and in the history of the modern psychology. If the mentioned intermix is avoided, then rather a consensus, not a debate is present.
} 
(matter) has not existed. As Revonsuo, a cognitive neuroscientist, writes "It is not a world of space-time, force fields, or subatomic particles we are talking about now, but a world of joys and sorrows, colours and sounds, thoughts and memories, embodiment and movement: a reality of lived experience and sensation. It is a world that, at the very least, senses its own existence, though it may not understand it or have the ability to conceptualise it as sensed existence" (Revonsuo 2006).

We would argue that soul (using the theological/religious terminology) and conscious mind (using the cognitive neuroscience terminology) are different descriptions of the very same phenomenon (for the review, see Carter 2000). Therefore, soul (read mind) can and should be studied scientifically within the cognitive neuroscience research program. We believe that it is the soul/mind phenomenon that is the shared (for the theological and neuroscientific points of view) fundamental reference which provides us with a starting point for a conceptual integration and unified research program.

Modern neuroscience no longer ignores the mind phenomenon and is progressively starting to address the mind-brain problem (for the review see Fingelkurts and Fingelkurts 2001): Physical ('objective') and mental ('subjective') processes are considered as two basic and complementary aspects of the same whole informational brain state (Fingelkurts et al. 2009). In this sense it is possible to come closer to understanding how something subjective has causal interactions with something objective.

Based on the above review of the existing literature and the proposed definition of religious experience, it is obvious that the human brain is the junction point of the material world and the world of ideas, the body and the mind, the objective and subjective (Fingelkurts and Fingelkurts 2004), the phenomenal organisation of the physical universe (Revonsuo 2006). The human mind (consciousness) is not just a reflection of physiological (internal) and physical (external) processes, but rather is a powerful active force: a mirror can not change creatively the object which it reflects, but the human mind is capable of this (see Section 8.2, argument (7) and comments on it).

In summary, the human mind appears as a partially isolated or partially independent pocket of thought and purpose, receiving its separate identity due to the constraining conditions of natural laws, the material composition of the individual brain, biological drive and genetics, and perhaps also through its own free agency (Clayton 2000). According to Clayton (2007) the emergence of the human mind in turn gives in principle the possibility for divine influences. In this scenario, no physical or natural laws are broken if there is an exchange of information between a divine source and conscious human agents: God could bring about changes in one's subjective thoughts, will and emotions the same way as the thoughts, will and emotions of other people do. Such influences do not require the addition of new causes or new energy into the system. 


\section{What can neuroscience offer?}

It follows from this paper that religious experience is a complex subjective psycho-neuro-physiologic phenomenon. In order to understand and explain it fully we need to describe its physical, biological, psychological, sociological and spiritual dimensions. At the moment neuroscience can not provide a reliable explanation for religious experience (see above). However, already today cognitive neuroscience in a broad sense may contribute to an overall description ${ }^{25}$ of religious experience with regards to biological and psychological dimensions. This is a very important task which needs to be performed before the reliable explanation for religious experience can be constructed. Therefore, currently there should be a methodological shift from "explanation" to "description." This will result in reduction of (a) misinterpretation of results, (b) desired logical speculations and (c) explanations which have limited phenomenological adequacy.

Considering "description" framework, neuroscience can specifically (a) identify neuropsychological components of the religious experience (describing what the brain is doing during a religious experience). By identifying the neuropsychological correlates of religious experience one can establish an objective, non-phenomenologically based but phenomenologically relevant definition of the religious experience; (b) demonstrate the reality of religious experience and show that religious experience is a complex state in its own right, which differs from other altered states of consciousness ${ }^{26}$ such as dreams, or pathologically-, pharmacologically- or self- induced hallucinations; and (c) distinguish states and traits ${ }^{27}$ components of religious experience.

In order to progress with a neuroscientific description of religious experience, several methodological issues should be addressed:

(1) It is important to find a way to register a true religious experience but not the other related phenomena such as religious practice or rituals, associated cognitive activity or pathologically or pharmacologically induced hallucinations. One possible solution may be to compare the state of

\footnotetext{
${ }^{25}$ The terms "description" and "explanation" are used here according to a common sense: "Description" is about observable or empirical phenomena (it answers the question What?). "Explanation" - provides a mechanism of observable or empirical phenomena (it answers the question Why? - why the observable or empirical phenomena is like it is? It provides a mechanism).

${ }^{26}$ Altered state of consciousness - a changed overall pattern of experience coupled with a changed pattern at the neurophysiological level (Kallio and Revonsuo 2003).

${ }^{27}$ State refers to the altered sensory, cognitive and self-referential awareness that can arise during religious experience, whereas trait refers to the lasting changes in these dimensions that persist in the person irrespective of being actively engaged in religious experience (West 1987; Austin 1998).
} 
a religious experience not to the subject's own baseline waking state but to a state which is induced by similar activity, however, without specific religious meaning (see, for example, Telles et al. 1998).

(2) It is important to choose appropriate level of neuroscientific description of religious experience. We believe that the appropriate level should articulate the phenomenal level of brain organization, and in particular, of cognition and consciousness (Revonsuo 2001). Recent work in different fields of cognitive neuroscience seems to support the idea that the "translation" from phenomenological/psychological constructs to brain activity should focus on the dynamic operations of large-scale cortical networks (see Edelman and Tononi 2000; Bressler and Kelso 2001; McIntosh et al. 2001; Revonsuo 2001; Varela et al. 2001; John 2002). Electroencephalography (EEG) is the correct measure to study the behaviour of large-scale neuronal networks, because it is a highly organized macro-level electrophysiological phenomenon in the brain, which captures the operations of large-scale cortical networks and which is remarkably correlated with behaviour, cognition and phenomenology (Nunez 2000; John 2001; Freeman 2003; see also recent detailed review Fingelkurts and Fingelkurts 2005; Fingelkurts et al. 2009). Behaviour, cognition and phenomenology in their turn have been supposed to be reflected in the temporal structure of EEG (see reviews Fingelkurts and Fingelkurts 2004; Kaplan et al. 2005). Moreover, among all non-invasive brain-imaging methods currently employed by Neuroscience EEG is (a) the method which measures brain activity directly in a millisecond time scale and (b) the most practical method with relatively simple, inexpensive and compact/portable equipment.

(3) It is important not only to correlate subjective (report on what was actually experienced by the individual) and objective (for example brain activity) measures, but also to use first-person reports to correlate internal experience with brain activity to guide EEG analysis (Varela 1996; Lutz et al. 2002).

(4) It is important to evaluate subjects on an individual basis because religious experience may vary phenomenologically across subjects. This permits researchers to reveal universal (common) and variable (individual) features of religious experience. Such findings may be important for science and be of interest to theology.

(5) Even though naturally occurring religious experience differs from a drug-induced one (see above), comparing drug-induced religious experience to naturally occurring religious phenomena 
within one experimental paradigm may allow for a better distinction between pathological and non-pathological religious experiences.

(6) Considering that normal religious experience can occur in pathological and normal conditions and that pathologic religious phenomena can occur in individuals with or without psychopathological disorders (Newberg and Lee 2005), it is important to study religious experience in psychiatric and neurological disorders.

(7) Using a framework of the Operational Architectonics ${ }^{28}$ of brain and mind functioning (Fingelkurts and Fingelkurts 2001, 2004, 2005, 2006; Fingelkurts et al 2009) and the phenomenon of functional isomorphism ${ }^{29}$ (Fingelkurts and Fingelkurts 2001, 2004) as a base, it would be possible to study and systematically describe the phenomenal level of brain organisation which constitutes the mental phenomena associated with religious experience. As such, it would be possible to give a subjectively/phenomenalogically plausible neurophysiological description of mental phenomena which are so important for the description of religious experience.

We believe that fulfillment of these methodological requirements will result in adequate neuroscientific description of religious experience. Such neuroscientific description of religious experience together with biological, psychological, sociological, phenomenological and theological descriptions will bring us closer to explanation of religious experience (which should be the next phase in the understanding the religious experience) and to the answer on the question: "Is our brain hardwired to believe in and produce God, or is our brain hardwired to perceive God?"

\section{The importance of the study of religious experience}

Contrary to the immediate intuition, the study of religious experience has significant importance not only for theology and philosophy, but also for science and clinical practice.

\footnotetext{
${ }^{28}$ Operational Architectonics defines the temporal structure of the information flow and the inter-area interactions within a spatial network of functional neuronal assemblies by examining topographic rapid transition processes (on the millisecond scale) in the scalp electroencephalogram (EEG) / magnetoencephalogram (MEG) and is a framework adequate to instantiate discrete conscious experiences without fundamentally violating the demand of its continuity (Fingelkurts and Fingelkurts 2006).

${ }^{29}$ Isomorphism is generally defined as a mapping of one entity into another having the same elemental structure, whereby the behaviours of the two entities are identically describable (Warfield 1977). A functional isomorphism on the other hand requires the functional connectivity between its component entities (Lehar, 2003). It is an extension to Müller's psychophysical postulate (Müller 1896), and Chalmers' principle of structural coherence (Chalmers 1995).
} 


\subsection{Importance for a scientific perspective}

We agree with Newberg and colleagues that considering that religious experience is the only state where a person claims to have broken the bounds of his/her own human self-consciousness and come into intimate contact with ultimate reality, it is very important to study religious experience because that may be the only way of solving the problem of how to get outside the subjective mind (see Newberg and d'Aquili 2000; Newberg et al. 2001a,b). As such, the study of religious experience may shed new light on (a) mind, consciousness, self and reality, and (b) the relationship between phenomenological characteristics, brain states, body physiology and behaviour. Moreover, it will contribute to the development of (a) an appropriate definition of religious experience, (b) methodology and measurement techniques, and (c) methods of analysis in order to study subjective phenomena in general.

\subsection{Importance for a clinical perspective}

The results of a study into religious experience will help therapists to determine whether a patient is experiencing a normal religious phenomenon, a pathological one, or both. The therapist would benefit in having a clearer understanding of the neuropsychological processes involved in the religious experience in that he or she would be able to treat pathologies associated with the religious experience appropriately.

Moreover, considering similarities between religious experience and schizophrenic states with religious content (Buckley 1981), the state of religious experience is arguably the most valuable state for understanding the relationship between religious activity, extra-personal brain mechanisms and schizophrenia.

\subsection{Importance for a theological perspective}

The results of such studies may (a) help to gain a better and deeper understanding of religious experience, (b) to gain a better understanding of the doctrine of the image of God, and eventually (c) contribute to theological and philosophical conceptualisations. These studies will enhance human knowledge of how religious experience affects the mind, brain, body and behaviour (Newberg and Lee 2005). 
12.4. Importance for a philosophical perspective

The results of a study into religious experience will provide evidence-based grounds for psychobiologically relevant conceptualisations of religious experience and subjective phenomena in general (versus abstract ones).

\section{Acknowledgement}

This work was partly supported by BM-Science Centre. Special thanks to Simon Johnson for skilful language editing. 


\section{References:}

Abdel-Khalek AM, Lester D (2007) Religiosity, health, and psychopathology in two cultures: Kuwait and USA. Mental Health, Religion \& Culture 10(5):537-550

Adcock RA, Thangavel A, Whitfield-Gabrieli S, Knutson B, Gabrieli JDE (2006) Reward-Motivated Learning: Mesolimbic Activation Precedes Memory Formation. Neuron 50:507-517

Aftanas LI, Golocheikine SA (2001) Human anterior and frontal midline theta and lower alpha reflect emotionally positive state and internalized attention: High-resolution EEG investigation of meditation. Neurosci Lett 310:57-60

Aghajanian GK, Marek GJ (1999) Serotonin and hallucinogens. Neuropsychopharmacology 21(2 suppl):16S-23S

Armstrong T (1985, August) Profound childhood religious experience. Paper presented at the 93rd Annual Convention of the American Psychological Association, Los Angeles, CA

Atran S (2002) In Gods We Trust: The evolutionary landscape of religion. Oxford, Oxford University

Augustine JR (1996) Circuitry and functional aspects of the insular lobe in primates including humans. Brain Res Brain Res Rev 22:229-244

Austin JH (1998) Zen and the brain: Toward an understanding of meditation and consciousness. The MIT Press, Cambridge, MA

Azari NP, Birnbacher D (2004) The role of cognition and feeling in religious experience: An interdisciplinary inquiry. Zygon 39(4):901-918

Azari NP, Nickel J, Wunderlich G, Niedeggen M, Hefter H, Tellmann L, Herzog H, Stoerig P, Birnbacher D, Seitz RJ (2001a) Neural correlates of religious experience. Eur J Neurosci 13(8):1649-1652

Azari NP, Nickel J, Wunderlich G, Niedeggen M, Hefter H, Tellmann L, et al. (2001b) Neural circuitry of religious experience. Paper presented at the 31rst Annual Meeting of the Society for Neuroscience, San Diego, CA, Society for Neuroscience

Baars BJ (2005) Subjective experience is probably not limited to humans: The evidence from neurobiology and behaviour. Conscious Cogn 14:7-21

Badawi K, Wallace RK, Orme-Johnson D, Rouzere AM (1984) Electrophysiologic characteristics of respiratory suspension periods occurring during the practice of the Transcendental Meditation program. Psychosom Med 46:267-276

Badgaiyan RD (2000) Executive control, willed actions, and nonconscious processing. Hum Brain Mapp 9:38-41

Barrett JL (2000) Exploring the Natural Foundations of Religion. Trends Cogn Sci 4(1):29-34

Barrett JL (2007) Is the spell really broken? Bio-psychological explanations of religion and theistic belief. Theology and Science 5(1):57-72

Barrett JL, Keil FC (1996) Conceptualizing a non-natural entity: anthropomorphism in God concepts. Cognit Psychol 31:219-247

Barrett JL, Richert RA (2003) Anthropomorphism or Preparedness? Exploring Children's God Concepts. Rev Relig Res 44(3):300-312

Bartels A, Zeki S (2000) The neural basis of romantic love. NeuroReport 11:3829-3834

Bartels A, Zeki S (2004) The neural correlates of maternal and romantic love. Neuroimage 21:1155-1166

Batson CD, Ventis WL (1982) Chapter 7. The religious experience: A social-psychological perspective. Oxford University Press, New York.

Bear DM (1979) Temporal lobe epilepsy—A syndrome of sensory-limbic hyperconnection. Cortex 15:357-384

Bear DM, Fedio P (1977) Quantitative analysis of interictal behavior in temporal lobe epilepsy. Arch Neurol 34:454-467

Bear D, Levin K, Blumer D, Chetham D, Reider J (1982) Interictal behavior in hospitalized temporal lobe epileptics: Relationship to idiopathic psychiatric syndromes. J Neurol Neurosurg Psychiatry 45:481-488

Beauregard M (2007) Mind does really matter: Evidence from neuroimaging studies of emotional self-regulation, psychotherapy, and placebo effect. Prog Neurobiol 81(4):218-236

Beauregard M, Paquette V (2006) Neural correlates of a mystical experience in Carmelite nuns. Neurosci Lett 405:186-190

Bechara A, Damasio AR, Damasio H, Anderson SW (1994) Insensitivity to future consequences following damage to human prefrontal cortex. Cognition 50:7-12 
Benedetti F, Lanotte M, Lopiano L, Colloca L (2007) When words are painful: unraveling the mechanisms of the nocebo effect. Neuroscience 147:260-271

Bennett JE, Trinder J (1977) Hemispheric laterality and cognitive style associated with Transcendental Meditation. Psychophysiology 14:293-296

Berdyaev NA (1937, translated 1939) Spirit and reality. YMCA-Press s.d., Paris, pp. 175

Bering JM (2004) The Evolutionary History of an Illusion: Religious Causal Beliefs in Children and Adults. In: Ellis B \& Bjorklund DF (eds) Origins of the Social Mind: Evolutionary Psychology and Child Development. Guilford Press, New York, pp 411-437

Blood A, Zatorre R (2001) Intensely pleasurable responses to music correlate with activity in brain regions implicated in reward and emotion. Proc Natl Acad Sci U S A 98:11818-11823

Bloom P (2007) Religion is Natural. Dev Sci 10:147-151

Borg J, Andrée B, Serstrom H, Farde L (2003) The Serotonin System and Spiritual Experiences. Am J Psychiatry 160:1965-1969

Bouchard TJJr, Lykken DT, McGue M, Segal NL, Tellegen A (1990) Sources of human psychological differences: the Minnesota Study of Twins Reared Apart. Science 250:223-228

Boyer P (2001) Religion Explained: Evolutionary Origins of Religious Thought. Basic Books, New York

Boyer P (2003) Religious thought and behaviour as by-products of brain function. Trends Cogn Sci 7(3):119-124

Bozarth MA (1991) The mesolimbic dopamine system as a model brain reward system. In: Willner P \& ScheelKrüger J (eds) The mesolimbic dopamine system: From motivation to action. John Wiley \& Sons, London, pp 301-330

Braam AW, Van den Eeden P, Prince MJ, Beekman AT, Kivela SL, Lawlor BA, Birkhofer A, Fuhrer R, Lobo A, Magnusson H, Mann AH, Meller I, Roelands M, Skoog I, Turrina C, Copeland JR (2001) Religion as a Cross-Cultural Determinant of Depression in Elderly Europeans: results from the Eurodep collaboration. Psychol Med 31(5):803-814

Bremmer J (1983) The early Greek concept of the soul. Princeton University Press, Princeton

Bressler SL, Kelso JAS (2001) Cortical coordination dynamics and cognition. Trends Cogn Sci 5:26-36

Brewerton TD (1994) Hyperreligiosity in psychotic disorders. J Nerv Ment Dis 182:302-304

Britton WB, Bootzin RR (2004) Near-death experiences and the temporal lobe. Psychol Sci 15:254-258

Brugger P, Graves RE (1997) Testing vs. believing hypotheses: Magical ideation in the judgment of contingencies. Cognit Neuropsychiatry 2:251-272

Bucke RM (1961) Cosmic Consciousness. Secaucus, NJ, Citadel

Buckley P (1981) Mystical experience and schizophrenia. Schizophr Bull 7:516-521

Burkert W (1996) Creation of the Sacred: Tracks of Biology in Early Religions. Harvard Univ Press, Cambridge, MA, pp 255

Byrd RC (1988) Positive Therapeutic Effects of Intercessory Prayer in a Coronary Care Unit Population. South Med J 81(7):826-829

Cahn BR, Polich J (2006) Meditation States and Traits: EEG, ERP, and Neuroimaging Studies. Psychol Bull 132:180-211

Calabrese P, Markowitsch H, Durwen H, Widlitzek H, Haupts M, Holinka B, Gehlen W (1996) Right temporofrontal cortex as critical locus for the ecphory of episodic memories. J Neurol Neurosurg Psychiatry 61:304-310

Carlton PL (1963) Cholinergic mechanisms in the control of behaviour by the brain. Psychol Rev 40:19-39

Carter BM (2000) The Salvation of Your Souls: But What Is a Soul? Perspectives on Science and Christian Faith 52(4): 242-254

Castelli F, Happe F, Frith U, Frith C (2000) Movement and mind: a functional imaging study of perception and interpretation of complex intentional movement patterns. Neuroimage 12:314-325

Cha KY, Wirth DP, Lobo RA (2001) Does prayer influence the success of in-vitro fertilization embryo transfer? Report of a masked, randomized trial. J Reprod Med 46:781-787

Chalmers DJ (1995) Facing up to the problems of consciousness. Journal of Consciousness Studies 2:200-219

Cicogna P, Natale V, Occhionero M, Bosinelli M (1998) A comparison of mental activity during sleep onset and morning awakening. Sleep 21(5):462-470 
Clark WH (1969) Chemical Ecstasy. Sheed \& Ward, New York

Clayton P (1999) Neuroscience, the Person and God: An Emergentist Account. In: Russell RJ, Murphy N, Meyering TC, Arbib M (eds) Neuroscience and the Person: Scientific Perspectives on Divine Action. Vatican Observatory Publications and the Center for Theology and the Natural Sciences

Clayton P (2000) The emergence of spirit. The center for theology and the natural sciences bulletin 20(4):3-20

Clayton P (2006) The emergence of spirit: from complexity to anthropology to theology? Theology and Science 4(3):291-307

Clayton P (2007) The impossible possibility: divine causes in the world of nature. Online paper, Retrieved from http://www.ctr4process.org/about/CoDirectors/clayton/papers.htm

Cohen BM, Carlezon WAJr (2007) Can’t get enough of that dopamine. Am J Psychiatry 164:543-546

Coles R (1990) The spiritual life of children. Houghton Mifflin

Collette F, Van der Linden M (2002) Brain imaging of the central executive component of working memory. Neurosci Biobehav Rev 26:105-125

Comings DE, Gonzales N, Saucier G, Johnson JP, MacMurray JP (2000) The DRD4 gene and the spiritual transcendence scale of the temperament index. Psychiatr Genet 10:185-189

Conze E (1993) A short history of Buddhism. Oneworld Pubns Ltd, 2nd edition

Cothran MM, Harvey PD (1986) Delusional thinking in psychotics: Correlates of religious content. Psychol Rep 58:191-199

Crinion J, Turner R, Grogan A, Hanakawa T, Noppeney U, Devlin JT, Aso T, Urayama S, Fukuyama H, Stockton K, Usui K, Green DW, Price CJ (2006) Language Control in the Bilingual Brain. Science 312(5779):15371540

Critchley HD, Wien S, Rotshtein P, Ohman A, Dolan RJ (2004) Neural systems supporting interoceptive awareness. Nat Neurosci 7:189-195

Csernansky JG, Leiderman DB, Mandabach M, Moses JAJr (1990) Psychopathology and limbic epilepsy: Relationship to seizure variables and neuropsychological function. Epilepsia 31:275-280

Cummings JL (1993) Frontal-subcortical circuits and human behavior. Arch Neurol 50:873-880

D’Onofrio BM, Eaves LJ, Murrelle L, Maes HH, Spilka B (1999) Understanding biological and social influences on religious affiliation, attitudes, and behaviors: A behavior genetic perspective. J Pers 67:953-984

Damasio AR (1999) The Feeling of What Happens: Body and Emotion in the Making of Consciousness. Harcourt Brace, New York

Damasio AR (1995) On some functions of the human prefrontal cortex. Ann N Y Acad Sci 769:241-251

Damasio AR, Tranel D, Damasio H (1990) Individuals with sociopathic behavior caused by frontal damage fail to respond autonomically to social stimuli. Behav Brain Res 41:81-94

Damasio AR, Grabowski TJ, Bechara A, Damasio H, Ponto LL, Parvizi J, Hichwa RD (2000) Subcortical and cortical brain activity during the feeling of self-generated emotions. Nat Neurosci 3:1049-1056

Danbolt NC (2001) Glutamate uptake. Prog Neurobiol 65(1):1-105

d'Aquili EG (1993) Apologia pro scriptura sua, or maybe we got it right after all. Zygon 28(2):251-266

d'Aquili EG, Newberg AB (1993) Religious and mystical states: A neuropsychological model. Zygon 28:177200

d'Aquili EG, Newberg AB (1999) The mystical mind. Probing the biology of religious experience. Fortress, Minneapolis, $\mathrm{MN}$.

Davis KD, Taylor KS, Hutchison WD, Dostrovsky JO, McAndrews MP, Richter EO, Lozano AM (2005) Human Anterior Cingulate Cortex Neurons Encode Cognitive and Emotional Demands. J Neurosci 25(37):8402-8406

de Araujo IE, Rolls ET, Kringelbach ML, McGlone F, Phillips N (2003) Taste-olfactory convergence, and the representation of the pleasantness of flavour, in the human brain. Eur J Neurosci 18:2059-2068

Decety J (1996) Do imagined and executed actions share the same neural substrate? Eur J Neurosci 3:87-93

Delgado MR, Nystrom LE, Fissell C, Noll DC, Fiez JA (2000) Tracking the hemodynamic responses to reward and punishment in the striatum. J Neurophysiol 84:3072-3077

Delgado MR, Locke HM, Stenger VA, Fiez JA (2003) Dorsal striatum responses to reward and punishment: effects of valence and magnitude manipulations. Cogn Affect Behav Neurosci 3:27-38

Diduca D, Joseph S (1997) Schizotypal traits and dimensions of religiosity. Br J Clin Psychol 36:635-638 
Dillbeck MC, Bronson EC (1981) Short-term longitudinal effects of the Transcendental Meditation technique on EEG power and coherence. Int J Neurosci 14:147-151

Dolan RJ (1999) On the neurology of morals. Nat Neurosci 11:927-929

Dolcos F, Kragel P, Wang L, McCarthy G (2006) Role of the inferior frontal cortex in coping with distracting emotions. NeuroReport 17:1591-1594

D'Onofrio BM, Eaves LJ, Murrelle L, Maes HH, Spilka B (1999) Understanding biological and social influences on religious affiliation, attitudes, and behaviors: a behavior genetic perspective. J Pers 67:953-984

Doya K (2000) Metalearning, neuromodulation, and emotion. In: Hatano G, Okada N, \& Tanabe H (eds) Affective Minds. Elsevier Science B.V., pp 101-104.

Dworkin SF, Chen AC, LeResche L, Clark DW (1983) Cognitive reversal of expected nitrous oxide analgesia for acute pain. Anesth Analg 62:1073-1077

Eaves L (2004) Genetic and social influences on religion and values. In: Malcolm J (ed) From Cells to Souls and Beyond: Changing Portraits of Human Nature Grand Rapids. MI: Eerdmans, pp 102-122

Eaves LJ, Martin NG, Heath AC (1990) Religious affiliation in twins and their parents: Testing a model of cultural inheritance. Behav Genet 20:1-22

Edelman GM, Tononi G (2000) A Universe of consciousness: How matter becomes imagination. Basic Books, New York

Ehrlichman H, Wiener MS (1980) EEG asymmetry during covert mental activity. Psychophysiology 17:228-235

Eichenbaum H (2000) A cortical-hippocampal system for declarative memory. Nat Rev Neurosci 1:41-50

Elliott FA (1990) Neurology of aggression and episodic dyscontrol. Sem Neurol 10:303-312

Ellis GFR (2001) Quantum theory and the macroscopic world. In: Russell RJ, Clayton P, Wegter-McNelly, K \& Polkinghorne J (eds) Quantum Mechanics. Scientific perspectives on divine action, vol 5, Vatican City State: Vatican Observatory Publications / Berkeley, CA: CTNS, pp 259-291

Eslinger PJ (1999) Orbital frontal cortex: behavioral and physiological significance (part II). Neurocase 5:299300

Eurostat survey, Special EUROBAROMETER 225 (2005, June). Social values, Science \& Technology

Evans EM (2000) The emergence of beliefs about the origin of species in school-age children. Merrill Palmer Q 46:221-254

Evans EM (2001) Cognitive and contextual factors in the emergence of diverse belief systems: Creation versus evolution. Cognit Psychol 42:217-266

Eysenck HJ, Eysenck SBG (1976) Psychoticism as a Dimension of Personality. Hodder and Stoughton, London

Faber PL, Lehmann D, Gianotti LRR, Kaelin M, Pascual-Marqui RD (2004, April) Scalp and intracerebral (LORETA) theta and gamma EEG coherence in meditation. Paper presented at the International Society for Neuronal Regulation, Winterthur, Switzerland.

Fallon BA, Liebowitz MR, Hollander E, Schneier FR, Campeas RB, Fairbanks J, et al (1990) The pharmacotherapy of moral or religious scrupulosity. J Clin Psychiatry 51:517-521

Menn A (1999) Father Alexander Menn answering questions. Alexander Menn Foundation, Moscow, pp 318

Feldman J, Rust J (1989) Religiosity, schizotypal thinking, and schizophrenia. Psychol Rep 65:587-593

Felician O, Ceccaldi M, Didic M, Thinus-Blanc C, Poncet M (2003) Pointing to body parts: a double dissociation study. Neuropsychologia 41:1307-1316

Fenwick PB (1987) Meditation and the EEG. In: West MA (ed) The psychology of meditation, New York: Clarendon Press, pp 104-117

Fenwick P, Galliano S, Coate MA, Rippere V, Brown D (1985) 'Psychic' sensitivity, mystical experience, head injury and brain pathology. Br J Med Psychol 58:35-44

Fergus F, Lothian A (1997) The way to eternity: Egyptian myth. Duncan Baird Publishers, Amsterdam

Fernstrom JD, Garattini S (1998, October) Introduction to the Symposium Proceedings. Presented at the International Symposium on Glutamate, Bergamo. Italy J Nutr 130:891S

Filley CM (1995) Neurobehavioral Anatomy. University Press of Colorado, Niwot, CO

Fincham JM, Anderson JR (2006) Distinct roles of the anterior cingulate and prefrontal cortex in the acquisition and performance of a cognitive skill. Proc Natl Acad Sci U S A 103(34):12941-12946 
Fingelkurts AnA, Fingelkurts AlA (2001) Operational architectonics of the human brain biopotential field: Towards solving the mind-brain problem. Brain and Mind 2(3):261-296

Fingelkurts AnA, Fingelkurts AlA (2004) Making complexity simpler: Multivariability and metastability in the brain. Int J Neurosci 114(7):843-862

Fingelkurts AnA, Fingelkurts AlA (2005) Mapping of the brain operational architectonics. Chapter 2. In: Chen FJ (ed) Focus on Brain Mapping Research. Nova Science Publishers, Inc, pp 59-98 URL $=\underline{\mathrm{http}} / / / \mathrm{www} \cdot \mathrm{bm}-$ science.com/team/chapt3.pdf

Fingelkurts AnA, Fingelkurts AlA (2006) Timing in cognition and EEG brain dynamics: discreteness versus continuity. Cogn Process 7:135-162

Fingelkurts AnA, Fingelkurts AlA, Neves CFH (2009) Phenomenological architecture of a mind and Operational Architectonics of the brain: the unified metastable continuum. J New Math Nat Comput 5(1):221-244

Fink G, Markowitsch HJ, Reinkemeier M, Bruckbauer T, Kessler J, Heiss W-D (1996) Cerebral representation of one's own past: neural networks involved in autobiographical memory. J Neurosci 16:4275-4282

Fischer R (1971) A Cartography of Understanding Mysticism. Science 174:897-904

Fiske AP, Haslam N (1997) Is obsessive-compulsive disorder a pathology of the human disposition to perform socially meaningful rituals? Evidence of similar content. J Nerv Ment Dis 185:211-222

Flavell JH (1979) Metacognition and cognitive monitoring: a new area of cognitive development inquiry. Am Psychol 34:906-911

Fletcher PC, Happe F, Frith U (1995) Other minds in the brain: a functional imaging study of theory of mind in story comprehension. Cognition 57:109-128

Fowler JW (1981) Stages of Faith. HarperCollins, San Francisco

Francis LJ, Wilcox C (1996) Prayer, church attendance, and personality revisited: A study among 16- to 19-yr-old girls. Psychol Rep 79:1265-1266

Freeman WJ (2003) Evidence from human scalp electroencephalograms of global chaotic itinerancy. Chaos 13:1067-1077

Freese TE, Miotto K, Reback CJ (2002) The effects and consequences of selected club drugs. J Subst Abuse Treat 23:151-156

Frith C, Dolan R (1996) The prefrontal cortex in higher cognitive functions. Cogn Brain Res 5:175-181

Frith CD, Frith U (1999) Interacting minds - a biological basis. Science 286:1692-1695

Fuster JM (1997) The Prefrontal Cortex: Anatomy, Physiology and Neuropsychology of the Frontal Lobe, $3^{\text {rd }}$ ed. Lippincott-Raven, Philadelphia, PA

Fuster JM (1999) Synopsis of function and dysfunction of the frontal lobe. Acta Psychiatr Scand 99:51-57

Gabrieli JD, Poldrack RA, Desmond JE (1998) The role of left prefrontal cortex in language and memory. Proc Natl Acad Sci U S A 95(3):906-913

Gallagher HL, Happe F, Brunswick N, Fletcher PC, Frith U, Frith CD (2000) Reading the mind in cartoons and stories: an fMRI study of theory of mind in verbal and nonverbal tasks. Neuropsychologia 38:11-21

Gallemore JLJr, Wilson WP, Rhoads JM (1969) The religious life of patients with affective disorder. Dis Nerv Syst 30:483-487

Gallup G, Castelli J (1990, 7 September) Gallup religion poll. Los Angeles Times Syndicate

Ganis G, Thompson WL, Kosslyn SM (2004) Brain areas underlying visual mental imagery and visual perception: an fMRI study. Brain Res Cogn Brain Res 20:226-241

Gaylord C, Orme-Johnson D, Travis F (1989) The effects of the Transcendental Meditation technique and progressive muscle relaxation on EEG coherence, stress reactivity, and mental health in black adults. Int J Neurosci 46:77-86

Gazzaniga MS (1970) The bisected brain. Appleton, New York

Gazzaniga MS (2005) The Ethical Brain. Dana Press, New York, pp 220 (Excerpt from pages 145-155)

Gemar MC, Kapur S, Segal ZV, Brown GM, Houle S (1996) Effects of self-generated sad mood on regional cerebral activity: a PET study in normal subjects. Depression 4:81-88

George MS, Ketter TA, Parekh PI, Herscovitch P, Post RM (1996) Gender differences in regional cerebral blood flow during transient self-induced sadness or happiness. Biol Psychiatry 40:859-871 
Getz GE, Fleck DE, Strakowski SM (2001) Frequency and severity of religious delusions in Christian patients with psychosis. Psychiatry Res 103:87-91

Giancola PR, Zeichner A (1994) Neuropsychological performance on tests of frontal-lobe functioning and aggressive behavior in men. J Abnorm Psychol 103:832-835

Gijsbers AJ (2003, July) The dialogue between neuroscience and theology. Paper presented at the Conference on Science and Christianity (COSAC) held at Avondale College, Cooranbong

Glennon RA (1990) Do classical hallucinogens act as 5-HT2 agonists or antagonists? Neuropsychopharmacology 3:509-517

Godefroy O, Cabaret M, Petit-Chenal V, Pruvo JP, Rousseaux M (1999) Control functions of the frontal lobes. Modularity of the central-supervisory system? Cortex 35:1-20

Goel V, Grafman J, Tajik J, Gana S, Danto D (1998) Modelling other minds. Brain 120:1805-1822

Goldman-Rakic PS (1987) Circuitry of primate prefrontal cortex and regulation of behaviour by representational memory. In: Mountcastle VB, Plum F, Geiger SR (eds) Handbook of Physiology, vol 5, American Physiological Society, Bethesda, MD, pp 373-417

Gordon H (1978) Left hemisphere dominance for rhythmic elements in dichotomically presented melodies. Cortex 14:58-70

Grafman J, Litvan I (1999) Importance of deficits in executive functions. Lancet 354:1921-1923

Grafman J, Schwab K, Warden D, Pridgen A, Brown HR, Salazar AM (1996) Frontal lobe injuries, violence, and aggression: a report of the Vietnam Head Injury Study. Neurology 46:1231-1238

Greene JD, Sommerville RB, Nystrom LE, Darley JM, Cohen JD (2001) An fMRI investigation of emotional engagement in moral judgment. Science 293:2105-2108

Gribov IA (1988) Schöpferische Activität- Wesen and Voraussetzung vor dem Hintergrund der sowjetischen Hirnhemisphärenforschung. Dynamische psychiatrie 106/107:378-395

Gribov IA (1992) Creativity and brain hemispheres: educational implications. European Journal for High Ability $3: 6-14$

Grossoehme DH, Cotton S, Leonard A (2007) Spiritual and religious experiences of adolescent psychiatric inpatients versus healthy peers. J Pastoral Care Counsel 61(3):197-204

Gusnard DA, Akbudak E, Shulman GL, Raichle ME (2001) Medial prefrontal cortex and self-referential mental activity: relation to a default mode of brain function. Proc Natl Acad Sci U S A 98:4259-4264

Hansen G, Jensen SB, Chandresh L, Hilden T (1988) The psychotropic effect of ketamine. J Psychoactive Drugs 20:419-425

Harris Interactive poll (2006) Retrieved from

http://www.harrisinteractive.com/news/allnewsbydate.asp?NewsID $=1131$

Hay D (1990) Religious Experience Today: Studying the Facts. London, Mowbray

Hebert R, Lehmann D, Tan G, Travis F, Arenander A (2005) Enhanced EEG alpha time-domain phase synchrony during Transcendental Meditation: Implications for cortical integration theory. Signal Processing 85:22132232

Hood RWJr, Spilka B, Hunsberger B, Corsuch R (1996) The Psychology of Religion: An Empirical Approach 2nd ed, Guilford, New York

Hossein Nasr S, Leaman O (1996) History of Islamic philosophy. Routledge, London - New York

Ingvar DH (1985) Memory of the future: an essay on the temporal organization of conscious awareness. Hum Neurobiol 4:127-136

Ingvar DH (1991) How shall we measure regional brain work? In: Lassen NA, Ingvar DH, Raichle ME, Friberg L (eds) Brain Work and Mental Activity. Munksgaard, Copenhagen, pp 346-359

Ito S, Stuphorn V, Brown JW, Schall JD (2003) Performance Monitoring by the Anterior Cingulate Cortex During Saccade Countermanding. Science 302(5642):120-122

James W (1902) The varieties of religious experience. Longmans, Green \& Company, New York

Jasper H, Penfield W (1954) Epilepsy and the Functional Anatomy of the Human Brain. 2nd edition. Brown and Co, Little

John ER (2001) A field theory of consciousness. Conscious Cogn 9:184-213

John ER (2002) The neurophysics of consciousness. Brain Res Brain Res Rev 39:1-28 
Johnson SC, Baxter LC, Wilder LS, Pipe JG, Heiserman JE, Prigatano GP (2002) Neural correlates of selfreflection. Brain 125:1808-1814

Joseph R (2001) The limbic system and the soul. Evolution and the Neuroanatomy of Religious Experience. Zygon, The Journal of Religion and Science 36:105-136

Jung CG, von Franz M-L (1964) Man and his Symbols. Doubleday \& Co., Inc, Garden City, New York

Kahn D, Stickgold R, Pace-Schott EF, Hobson JA (2000) Dreaming and waking consciousness: a character recognition study. Sleep Res 9(4):317-325

Kallio S, Revonsuo A (2003) Hypnotic phenomena and altered states of consciousness: A multilevel framework of description and explanation. Contemporary Hypnosis 20:111-164

Kaplan AYa, Fingelkurts AnA, Fingelkurts AlA, Borisov SV, Darkhovsky BS (2005) Nonstationary nature of the brain activity as revealed by EEG/MEG: Methodological, practical and conceptual challenges. Signal Processing 85:2190-2212

Karnath H-O (2001) New insights into the functions of the superior temporal cortex. Nat Rev Neurosci 2:568-576

Katz Z (1971) Sociology of religion in the USSR: A beginning? Slavic Rev 30(4):870-875

Kelley WM, Macrae CN, Wyland CL, Caglar S, Inati S, Heatherton TF (2002) Finding the self? An event-related fMRI study. J Cogn Neurosci 14:785-794

Kelemen D (2004) Are children "intuitive theists"? Reasoning about purpose and design in nature. Psychol Sci 15(5):295-301

Kelemen D, Callanan M, Casler K, Pérez-Granados D (2005) Why things happen: Teleological explanation in parent-child conversations. Dev Psychol 41:251-264

Kim J (1992) "Downward causation" in emergentism and nonreductive physicalism. In: Beckermann A, Flohr H, Kim J (eds) Emergence of reduction? Essays on the prospects of nonreductive physicalism. Walter de Gruyter, Berlin, pp 119-138

Kim K, Hwu H, Zhang LD, Lu MK, Park KK, Hwang TJ, Kim D, Park YC (2001).Schizophrenic delusions in Seoul, Shanghai and Taipei: A transcultural study. Journal of the Korean Medical Society 16:88-94

King RAH (2005) Common to body and soul: Philosophical approaches to explaining living behaviour in GrecoRoman antiquity. Walter de Gruyter, Berlin.

Kirk KM, Eaves LJ, Martin NG (1999) Self-transcendence as a measure of spirituality in a sample of older Australian twins. Twin Res 2:81-87

Kjaer TW, Nowak M, Kjaer KW, Lou AR, Lou HC, John F (2001) Precuneus-prefrontal activity during awareness of visual verbal stimuli. Conscious Cogn 10(3):356-365

Kjaer TW, Bertelsen C, Piccini P, Brooks D, Alving J, Lou HC (2002) Increased dopamine tone during meditation-induced change of consciousness. Cogn Brain Res 13:255-259

Klaf FS, Hamilton JG (1961) Schizophrenia-A hundred years ago and today. J Ment Sci 107: 819-827

Klima G (1984) Libellus pro Sapiente: A criticism of Allan Bäck's argument against St. Thomas Aquinas's theory of the incarnation. New Scholasticism 58:207-219.

Knight RT, Garbowecky M (1995) Escape from linear time: Prefrontal cortex and conscious experience. In: Gazzaniga MS (ed) The cognitive neurosciences. MIT Press, Boston, pp 1357-1371

Koenig HG, Cohen HJ (eds) (2002) The Link between Religion and Health: Psychoneuroimmunology and the Faith Factor. Oxford University Press

Koenig HG, McCullough ME, Larson DB (2001) Handbook of religion and health. Oxford University Press, New York

Kohlmetz C, Kopiez R, Altenmuller E (2003) Stability of motor programs during a state of meditation: electrocortical activity in a pianist playing 'Vexations' by Erik Satie continuously for 28 hours. Music and Psychology Research 31(2):173-186

Kringelbach ML, O'Doherty J, Rolls ET, Andrews C (2003) Activation of the human orbitofrontal cortex to a liquid food stimulus is correlated with its subjective pleasantness. Cereb Cortex 13:1064-1071

Krippner S, Jaeger C, Faith L (2001) Identifying and utilizing spiritual content in dream reports. Dreaming 11:127-147

Kroll J, Sheehan W (1989) Religious beliefs and practices among 52 psychiatric in patients in Minnesota. Am J Psychiatry 146:67-72 
Krummenacher P, Brugger P, Fahti M, Mohr C (2002, July) Dopamine, paranormal ideation, and the detection of meaningful stimuli. Poster presentation at the 3rd Forum of European Neuroscience, Paris, France

Kune GA, Kune S, Watson LF (1993) Perceived religiousness is protective for colorectal cancer: data from the Melbourne Colorectal Cancer Study. J R Soc Med 86:645-647

Lane RD, Nadel L (2000) Cognitive Neuroscience of Emotion. Oxford UP, New York

Lane RD, Fink GR, Chau PML, Dolan RJ (1997a) Neural activation during selective attention to subjective emotional responses. NeuroReport 8:3969-3972

Lane RD, Reiman EM, Ahern GL, Schwartz GE, Davidson RJ (1997b) Neuroanatomical correlates of happiness, sadness, and disgust. Am J Psychiatry 154:926-933

Lane RD, Reiman EM, Axelrod B, Yun LS, Holmes A, Schwartz GE (1998) Neural correlates of levels of emotional awareness. Evidence of an interaction between emotion and attention in the anterior cingulate cortex. J Cogn Neurosci 10:525-535

Lapierre D, Braun CMJ, Hodgings S (1995) Ventral frontal deficits in psychopathy: neuropsychological test findings. Neuropsychologia 33:139-151

Larson DB, Swyers JP, McCullough ME (eds) (1998) Scientific Research on Spirituality and Health: A Consensus Report. National Institute for Healthcare Research, Washington, D.C.

Leary T (1964) The Religious Experience. Psychedelic Review 1:324-346

Leary T, Clark WH (1963) Religious Implications of Consciousness Expanding Drugs. Relig Educ 58(2):251-256

Lehar S (2003) Gestalt isomorphism and the primacy of subjective conscious experience: A gestalt bubble model. Behav Brain Sci 26:375-408

Lehmann D, Faber PL, Achermann P, Jeanmonod D, Gianotti RR, Pizzagalli D (2001) Brain sources of EEG gamma frequency during volitionally meditation-induced, altered states of consciousness, and experience of the self. Psychiatry Res 108:111-121

Levy R, Friedman HR, Davachi L, Goldman-Rakic PS (1997) Differential Activation of the Caudate Nucleus in Primates Performing Spatial and Nonspatial Working Memory Tasks. J Neurosci 17(10):3870-3882

Levy J, Trevarthen C (1976) Metacontrol of hemispheric function in human split-brain patients. J Exp Psychol Hum Percept Perform 2:299-312

Lewis CA (1994) Religiosity and obsessionality: The relationship between Freud's “religious practices". J Psychol 128:189-196

Lewis-Williams JD, Dowson T (1988) The signs of the times: Entopic phenomena in Upper Paleolithic art. Current Anthropology 29: 201-245

Liebovici L (2001) Effects of remote, retroactive incessory prayer on outcomes in patients with bloodstream infection: randomised controlled trial. Br Med J 323:1450-1451

Lobusov EV, Fingelkurts AlA, Fingelkurts AnA, Kaplan AYa (2001) EEG analysis of deep relaxation states induced by QiGong practice. Vestnik Moskovskogo Universiteta (Bulletin of Moscow University). Series 16. Biology, 3:36-43 (in Russian)

Logan RK (2006) The extended mind model of the origin of language and culture. In: Nathalie G, Jean P, Van B, Diederik A (eds) Evolutionary epistemology, language and culture. Springer, Dordrecht

Luria AR (1966) Higher Cortical Functions in Man. Basic Books, New York

Lutz A, Lachaux JP, Martinerie J, Varela FJ (2002) Guiding the study of brain dynamics by using first-person data: Synchrony patterns correlate with ongoing conscious states during a simple visual task. Proc Natl Acad Sci U S A 99:1586-1591

Luu P, Posner MI (2003) Anterior cingulate cortex regulation of sympathetic activity. Brain 126(10):2119-2120

MacDonald DA, Holland D (2002) Spirituality and complex partial epileptic-like signs. Psychol Rep 91:785-792

Maddock RJ (1999) Retrosplenial cortex and emotion. New insights from functional imaging of the human brain. TINS 22:310-316

Maddock RJ, Garrett AS, Buonocore MH (2003) Posterior cingulate cortex activation by emotional words: fMRI evidence from a valence decision task. Hum Brain Mapp 18:30-41

Makarec K, Persinger MA (1985) Temporal lobe signs: electroencephalographic validity and enhanced scores in special populations. Percept Mot Skills 60(3):831-842 
Maltby J (1997) Personality correlates of religiosity among adults in the Republic of Ireland. Psychol Rep $81: 827-831$

Mandell A (1980) Toward a Psychobiology of Transcendence: God in the Brain. In: Davidson JM, Davidson RJ (eds) The Psychobiology of Consciousness. Plenum, N.Y.

Markowitsch HJ, Vandekerckhovel MM, Lanfermann H, Russ MO (2003) Engagement of lateral and medial prefrontal areas in the ecphory of sad and happy autobiographical memories. Cortex 39:643-665

Marks L (2005) Religion and Bio-Psycho- Social Health: A Review and Conceptual Model. J Relig Health 44(2):173-186

Marshall P (2005) Mystical encounters with the natural world. Experiences and explanations. Oxford University Press, pp 324

Matthews DA, Marlowe SM, Macnutt FS (2000) Effects of prayer on patients with rheumatoid arthritis. South Med J 93(12):1177-1186

McDougall I, Brown FH, Fleagle JG (2005) Stratigraphic placement and age of modern humans from Kibish, Ethiopia. Nature 433: 733-736

McIntosh AR, Fitzpatrick SM, Friston KJ (2001) On the marriage of cognition and neuroscience. NeuroImage 14:1231-1237

McGuire PK, Silbersweig DA, Frith CD (1996b) Functional neuroanatomy of verbal self-monitoring. Brain 119:907-917

McGuire PK, Paulesu E, Frackowiak RSJ, Frith CD (1996a) Brain activity during stimulus independent thought. Neuroreport 7:2095-2099

Meck WH (1996) Neuropharmacology of timing and time perception. Cogn Brain Res 3:227-242

Menn A (1997) History of religion. In search of direction, truth, and life. V. II. Moscow: Slovo, pp. 463.

Menn A (1999) Menn answering questions.: Alexander Menn Foundation, Moscow, pp 318

Mesulam M-M (1986) Frontal cortex and behavior. Ann Neurol 19:320-325

Metcalfe J, Shimamura AP (1994) Metacognition: knowing about knowing. MIT Press, Cambridge, MA

Miotto EC, Bullock P, Polkey CE, Morris RG (1996) Spatial working memory and strategy formation in patients with frontal lobe excisions. Cortex 32:613-630

Mithen S (1996) The prehistory of the mind: The cognitive origins of art and science. Thames and Hudson, London

Mithen S (1999) Symbolism and the supernatural. In: Dunbar R, Knight C, Power C (eds) The Evolution of Culture. Rutgers University Press: New Brunswick, NJ, pp 147-171

Moghaddam B (2003) Bringing order to the glutamate chaos in schizophrenia. Neuron 40(5):881-884

Morneau DM, MacDonald DA, Holland CJ (1996) A confirmatory study of the relation between self-reported complex partial epileptic signs, peak experiences and paranormal beliefs. Br J Clin Psychol 35:627-630

Morris JS, Ohman A, Dolan RJ (1999) A subcortical pathway to the right amygdala mediating "unseen" fear. Proc Natl Acad Sci U S A 96:680-1685

Muhammad Ali M (2002) The Holy Qur'an with English translation and commentary. Ahmadiyya Anjuman Isha'at Islam Lahore Inc, USA

Müller GE (1896) Zur psychophysik der gesichtsempfindungen. Zeitschrift für Psychologie 10:1-82

Muramoto $\mathrm{O}$ (2004) The role of the medial prefrontal cortex in human religious activity. Med Hypotheses 62:479-485

Ndetei DM, Vadher A (1985) Content of grandiose phenomenonology across cultures. Acta Psychiatr Scand 72:38-39

Neggers SF, Van der Lubbe RH, Ramsey NF, Postma A (2006) Interactions between ego- and allocentric neuronal representations of space. Neuroimage 31(1):320-331

Nevskaja AA, Leushina LI (1990) Hemispheres asymmetry and visual images recognition. Nauka, Leningrad

Newberg AB, d'Aquili EG (1994) The near death experience as archetype: A model for 'prepared' neurocognitive processes. Anthropology of Consciousness 5:1-15

Newberg AB, d'Aquili EG (2000) The neuropsychology of religious and spiritual experience. Journal of Consciousness Studies 7(11-12):251-266 
Newberg AB, Lee BY (2005) The neuroscientific study of religious and spiritual phenomena: or why god doesn't use biostatistics. Zygon 40(2):469-489

Newberg AB, d'Aquili EG, Rause VP (2001) Why God Won't Go Away: Brain Science and the Biology of Belief. Ballantine, New York

Newberg AB, Alavi A, Baime M, Pourdehnad M, Santanna J, d'Aquili E (2001) The measurement of regional cerebral blood flow during the complex cognitive task of meditation: a preliminary SPECT study. Psychiatry Res 2:113-122

Newberg AB, Pourdehnad M, Alavi A, d'Aquili EG (2003) Cerebral blood flow during meditative prayer: preliminary findings and methodological issues. Percept Mot Skills 97:625-630

Norenzayan A, Heine SJ (2005) Psychological universals: what are they and how can we know? Psychol Bull 131(5):763-784

Nunez PL (2000) Toward a quantitative description of large-scale neocortical dynamic function and EEG. Behav Brain Sci 23:371-437

Olson JM, Vernon PA, Harris JA, Jang KL (2001) The heritability of attitudes: A study of twins. J Pers Soc Psychol 809(6):845-860

Ornstein R (1972) The psychology of consciousness. W H Freeman, San Francisco

Oser FK (1991) The development of religious judgement. New Dir Child Dev 52:5-25

Padoa-Schioppa C, Assad JA (2006) Neurons in the orbitofrontal cortex encode economic value. Nature 441(7090):223-226

Pagano RR, Warrenburg S (1983) Meditation: In search of a unique effect. In: Davidson RJ, Schwartz GE, Shapiro D (eds) Consciousness and self-regulation, Vol 3, Plenum Press, New York

Pardo JV, Pardo PJ, Raichle ME (1993) Neural correlates of self-induced dysphoria. Am J Psychiatry 150:713719

Perry EK, Perry RH (1995) Acetylcholine and hallucinations: Disease-related compared to drug-related alterations in human consciousness. Brain Cogn 28:240-258

Persinger MA (1984) People who report religious experiences may also display enhanced temporal-lobe signs. Percept Mot Skills 58:963-975

Persinger MA (1991) Preadolescent religious experience enhances temporal lobe signs in normal young adults. Percept Mot Skills 72:453-454

Persinger MA (1993) Vectorial cerebral hemisphericity as differential sources for the sensed presence, mystical experiences and religious conversions. Percept Mot Skills 76(3 Pt 1):915-930

Persinger MA, Makarec K (1987) Temporal lobe epileptic signs and correlative behaviors displayed by normal populations. J Gen Psychol 1114:179-195

Peters E, Day S, McKenna J, Orbach G (1999) Delusional ideation in religious and psychotic populations. Br J Clin Psychol 38:83-96

Previc FH (2006) The role of the extrapersonal brain systems in religious activity. Conscious Cogn 15:500-539

Pribram KH (1973) The primate frontal cortex - Executive of the brain. In: Pribram KH, Luria AR (eds) Psychophysiology of the frontal lobes. Academic Press, New York, pp 293-314

Proudfoot W (1985) Religious experience. University of California Press, Berkeley, CA

Radin D, Nelson R (2002, October) Meta-analysis of mind-matter interaction experiments, 1959 to 2000. In: Chez RA (ed) Proceedings for participants of the Conference on the Science and Spirituality of Healing. Home Moravian Church, Old Salem, NC, pp 54-65

Raine A, Yang Y (2006) Neural foundations to moral reasoning and antisocial behavior. Soc Cogn Affect Neurosci 1:203-213

Rechtschaffen A, Verdone P, Wheaton J (1963a) Reports of mental activity during sleep. Can Psychiatr Assoc J 8:409-414

Rechtschaffen A, Vogel G, Shaikun G (1963b) Interrelatedness of mental activity during sleep. Arch Gen Psychiatry 9:536-547

Reiman EM, Lane RD, Ahern GL, Schwartz GE, Davidson RJ, Friston KJ, Yun LS, Chen K (1997) Neuroanatomical correlates of externally and internally generated human emotion. Am J Psychiatry 154:918925 
Revonsuo A (1995) Consciousness, dreams, and virtual realities. Philosophical Psychology 8:35-58

Revonsuo A (2001) Can functional brain imaging discover consciousness in the brain? Journal of Consciousness Studies 8:3-23

Revonsuo A (2006) Inner Presence. Consciousness as a Biological Phenomenon. The MIT Press

Richert RA, Barrett JL (2006) The child's God and cognitive development. The encyclopaedia of spiritual development in childhood and adolescence. Sage Publishing, Thousand Oaks, CA

Roberts AC, Wallis JD (2000) Inhibitory control and affective processing in the prefrontal cortex: neuropsychological studies in the common marmoset. Cereb Cortex 10:252-262

Robinson E (1983) The original vision: A study of the religious experience of childhood. Harper San Francisco, San Francisco

Robinson I (2000) Can an atheist have a religious experience. Australian Rationalist 54:5-16

Rohde E (1925) Psyche: The cult of souls and the belief in immortality among the Greeks. Routledge \& Kegan Paul, London

Rolls ET, Kringelbach ML, de Araujo IE (2003) Different representations of pleasant and unpleasant odours in the human brain. Eur J Neurosci 18:695-703

Rolston H (2005) Genes, brains, minds: The human complex. Chapter one. In: Bulkeley K, (ed) Soul, psyche, brain: New directions in the study of religion and brain-mind science. Palgrave Macmillan, New York, pp 1035

Roman RE, Lester D (1999) Religiosity and mental health. Psychol Rep 85:1088

Rosse RB, Collins JPJr, Fay-McCarthy M, Alim TN, Wyatt RJ, Deutsch SI (1994) Phenonemonologic comparison of the idiopathic psychosis of schizophrenia and drug-induced cocaine and phencyclidine psychoses: A retrospective study. Clin Neuropharmacol 17:359-369

Roth BL, Baner K, Westkaemper R, Siebert D, Rice KC, Steinberg S, Ernsberger P, Rothman RB (2002) Salvinorin A: a potent naturally occurring nonnitrogenous kappa opioid selective agonist. Proc Natl Acad Sci U S A 99:11934-11939

Ruby P, Decety J (2003) What you believe versus what you think they believe: a neuroimaging study of conceptual perspective-taking. Eur J Neurosci 17:2475-2480

Ruby P, Sirigu A, Decety J (2002) Distinct areas in parietal cortex involved in long-term and short-term action planning: A PET investigation. Cortex 38(3):321-339

Rueckert L, Grafman J (1996) Sustained attention deficits in patients with right frontal lesions. Neuropsychologia 34:953-963

Runehov ALC (2004) Sacred or Neural: Neuroscientific Explanations of Religious Experience. A Philosophical Evaluation, Uppsala University Press: Uppsala

Runions JE (1979) The mystic experience: A psychiatric reflection. Can J Psychiatry 24:147-151

Sarter M, Bruno JP (1998) Cortical acetylcholine, reality distortion, schizophrenia, and Lewy Body dementia: Too much or too little cortical acetylcholine? Brain Cogn 38:297-316

Saver JL, Rabin J (1997) The neural substrates of religious experience. J Neuropsychiatry Clin Neurosci 9:498510

Saxe R, Kanwisher N (2003) People thinking about thinking people. The role of the temporo-parietal junction in "theory of mind". NeuroImage 19:1835-1842

Saxe R, Wexler A (2005) Making sense of another mind: the role of the right temporoparietal junction. Neuropsychologia 43:1391-1399

Saxe R, Carey S, Kanwisher N (2004) Understanding other minds: Linking developmental psychology and functional neuroimaging. Annu Rev Psychol 55:1-27

Schuman M (1980) The psychophysiological model of meditation and altered states of consciousness: A critical review. In: Davidson JM, Davidson RJ (eds) The psychobiology of consciousness. Plenum Press, New York

Seiter C (2002, April) Transferred potentials - fact or artefact? Results of a pilot study. Paper presented at the Conference "Toward a Science of Consciousness", Tucson, AZ

Shallice T, Evans ME (1978) The involvement of the frontal lobes in cognitive estimation. Cortex 14:294-303

Shallice T, Fletcher P, Frith CD, Grasby P, Frackowiak RSJ, Dolan RJ (1994) Brain regions associated with aquisition and retrieval of verbal episodic memory. Nature 368:633-635 
Shaner A (1999) Delusions, superstitious conditioning and chaotic dopamine dynamics. Med Hypotheses 52:119123

Sherman SM (2005) The role of the thalamus in cortical function: not just a simple relay. Thalamus Relat Syst 3:205-216

Sherman SM, Guillery RW (2005) Exploring the thalamus and its role in cortical function. Second Edition. Cambridge, MIT Press

Sim MK, Tsoi WF (1992) The effects of centrally acting drugs on the EEG correlates of meditation. Biofeedback Self Regul 17:215-220

Smith C, Denton ML (2005) Soul searching: The religious and spiritual lives of American teenagers. Oxford University Press, New York, NY

Smythies J (1999a) The biochemical basis of coma. Psycoloquy 10(026)

ftp://ftp.princeton.edu/pub/harnad/Psycoloquy/1999.volume.10/psyc.99.10.026.coma-biochemistry.1.smythies http://www.cogsci.soton.ac.uk/cgi/psyc/newpsy?10.026

Smythies J (1999b) Redox mechanisms at the glutamate synapse and their significance: a review. Eur J Pharmacol 370:1-7

Sosis R (2000) Religion and intragroup cooperation: Preliminary results of a comparative analysis of utopian communities. Cross Cult Res 34(1):77-88

Sosis R, Bressler E (2003) Co-operation and Commune Longevity: A Test of the Costly Signaling Theory of Religion. Cross Cult Res 37(2):11-39

Spencer J (1975) The mental health of Jehovah's Witnesses. Br J Psychiatry 126:556-559

Sperber D (1996) Explaining Culture: A Naturalistic Approach. Blackwell

Sperry RW, Gazzaniga M, Bogen I (1969) Interhemispheric relationships: the neocortical commissures, syndromes of hemisphere disconnection. In: Vinken PJ, Bruyn GW (eds) Handook of clinical neurology, vol.4: Disorders of speech, perception, and symbolic behaviour, Amsterdam: Elsevier, pp. 237-290

Spilka B, Hood R, Gorsuch R (1984) The psychology of religion: An empirical approach. Prentice-Hall, Englewood Cliffs, NJ

States BO (2000) Dream bizarreness and inner thought. Dreaming 10(4):179-192

Stower L, Ryan MA (1998) Vision of the whole child: The significance of religious experiences in early childhood. Aust J Early Child 23(1):1-4

Stuss DT, Benson DF (1984) Neuropsychological studies of the frontal lobes. Psychol Bull 95:3-28

Swinburne R (1986) The evolution of the soul. Clarendon Press, Oxford

Takahashi T, Murata T, Hamada T, Omori M, Kosaka H, Kikuchi M, Yoshida H, Wad Y (2005) Changes in EEG and autonomic nervous activity during meditation and their association with personality traits. Int $\mathrm{J}$ Psychophysiol 55:199-207

Tamminen K (1994) Religious experiences in childhood and adolescence: A viewpoint of religious development between the ages of 7 and 20. Int J Psychol Relig 4:61-85

Taves A (2005) Religious Experience. In: Encyclopedia of religion, 2nd edition, Macmillan, vol 11, 7736-7750

Taylor JG (2001) The central role of the parietal lobes in consciousness. Conscious Cogn 10(3):379-417

Tek C, Ulug B (2001) Religiosity and religious obsessions in obsessive-compulsive disorder. Psychiatry Res 104:99-108

Telles S, Nagarathna R, Nagendra H R (1998) Autonomic changes while mentally repeating two syllables-one meaningful and the other neutral. Indian J Physiol Pharmacol 42(1):57-63

Tolin DF, Abramowitz JS, Kozak MJ, Foa EB (2001) Fixity of belief, perceptual aberration, and magical ideation in obsessive-compulsive disorder. J Anxiety Disord 15:501-510

Travis F (2001) Autonomic and EEG patterns distinguish transcending from other experiences during Transcendental Meditation practice. Int J Psychophysiol 42:1-9

Travis F, Wallace RK (1999) Autonomic and EEG patterns during eyes-closed rest and Transcendental Meditation (TM) practice: The basis for a neural model of TM practice. Conscious Cogn 8:302-318

Trinkaus E, Shipman P (1993) The Neandertals: Changing the image of mankind. Alfred A. Knopf Pub: New York, pp. 454 
Truett KR, Eaves LJ, Meyer JM, Heath AC, Martin NG (1992) Religion and Education as mediators of attitudes: a multivariate analysis. Behav Genet 22:43-62

Tsapakis EM, Travis MJ (2002) Glutamate and psychiatric disorders. Advances in Psychiatric Treatment 8:189197

Tulving E, Kapur S, Craik FIM, Markowitsch HJ, Houle S (1994) Hemispheric encoding/retrieval assymetry in episodic memory: positron emission tomography findings. Proc Natl Acad Sci USA 91:2016-2020

Unger M (1963) Mescaline, LSD, psilocybin and personality change. Psychiatry J Study Interpers Process 26(2):111-125

Vandenberghe R, Nobre AC, Price CJ (2002) The response of left temporal cortex to sentences. J Cogn Neurosci 14(4):550-560

Varela FJ (1996) Neurophenomenology, a methodological remedy for the hard problem. Journal of Consciousness Studies 3:330-349

Varela FJ, Thompson E (2003) Neural synchrony and the unity of mind: A neurophenomenological perspective. In: Cleeremans A (ed) The Unity of Consciousness. Oxford University Press, London, pp 266-287

Varela F, Lachaux J-P, Rodriguez E, Martinerie J (2001) The brainweb: Phase synchronization and large-scale integration. Nat Rev Neurosci 2:229-239

Verdoux H, van Os J, Maurice-Tison S, Gay B, Salamon R, Bourgeois M (1998) Is early adulthood a critical developmental stage for psychosis proneness. A survey of delusional ideation in normal subjects. Schizophr Res 29:247-254

Vogt BA, Finch DM, Olson CR (1992) Functional heterogeneity in cingulated cortex: the anterior executive and posterior evaluative regions. Cereb Cortex 2:435-443

Wackermann J (2004) Dyadic correlations between brain functional states: Present facts and future perspectives.

Mind Matter 2(1):105-122

Wagner AD, Pare-Blagoev EJ, Clark J, Poldrack RA (2001) Recovering meaning: left prefrontal cortex guides controlled semantic retrieval. Neuron 31(2):329-338

Waller NG, Kojetin BA, Bouchard TJ, Lykken DT, Telelgen A (1990) Genetic and environmental influences on religious interests, attitudes, and values. Psychol Sci 1:138-142

Capps WH (1995) Religious studies: The making of a discipline. Fortress Press, Minneapolis

Warfield JN (1977) Crossing theory and hierarchy mapping. IEEE Trans Syst Man Cybern, SMC-7:505-523

Watanabe M (1996) Reward expectancy in primate prefrontal neurons. Nature 382:629-632

Watanabe S, Huber L (2006) Animal logics: Decisions in the absence of human language. Anim Cogn 9:235-245

Waxman SG, Geschwind N (1975) The interictal behavior syndrome of temporal lobe epilepsy. Arch Gen Psychiatry $32: 1580-1586$

West MA (1987) The psychology of meditation. Clarendon Press, New York

Wildman W, Brothers L (1999) A neuro-psychological-semiotic model of religious experiences. In: Russel RJ, Murphy N, Meyering TC, Arbib MA (eds) Neuroscience and the person. Scientific perspectives on divine action, Vol 4, Vatican City State: Vatican Observatory Publications / Berkeley, CA: CTNS, pp 347-416

White J, Joseph S, Neil A (1995) Religiosity, psychoticism, and schizotypal traits. Pers Individ Dif 19:847-851

Wright P (1989) The Nature of the shamanic state of consciousness: A Review. J Psychoactive Drugs 21(1):2533

Wuerfel J, Krishnamoorthy ES, Brown RJ, Lemieux L, Koepp M, Tebartz van Elst L, Trimble MR (2004) Religiosity is associated with hippocampal but not amygdala volumes in patients with refractory epilepsy. $\mathrm{J}$ Neurol Neurosurg Psychiatry 75:640-642

Wuthnow R (1992) Rediscovering the sacred. Eerdmans, Grand Rapids, MI

Youde F (2003) Body and soul: Comparative studies in biblical Judaism, Greek philosophy and Medieval Christianity. Twenty-First World Congress of Philosophy, August 10-17, 2003, Istanbul, Turkey

Zald DH, Kim SW (1996) The anatomy and function of the orbito-frontal cortex I: anatomy, neurocircuitry, and obsessive-compulsive disorder. J Neuropsychiatry Clin Neurosci 8:125-138 